\title{
De arbeidsmarkt voor technisch opgeleiden : haalbaarheidsonderzoek
}

Citation for published version (APA):

Willems, E. (1993). De arbeidsmarkt voor technisch opgeleiden : haalbaarheidsonderzoek.

Researchcentrum voor Onderwijs en Arbeidsmarkt, Faculteit der Economische Wetenschappen. ROA Reports No. 12 https://doi.org/10.26481/umarep.1993012

Document status and date:

Published: 01/01/1993

DOI:

10.26481/umarep.1993012

Document Version:

Publisher's PDF, also known as Version of record

\section{Please check the document version of this publication:}

- A submitted manuscript is the version of the article upon submission and before peer-review. There can be important differences between the submitted version and the official published version of record.

People interested in the research are advised to contact the author for the final version of the publication, or visit the DOI to the publisher's website.

- The final author version and the galley proof are versions of the publication after peer review.

- The final published version features the final layout of the paper including the volume, issue and page numbers.

Link to publication

\footnotetext{
General rights rights.

- You may freely distribute the URL identifying the publication in the public portal. please follow below link for the End User Agreement:

www.umlib.nl/taverne-license

Take down policy

If you believe that this document breaches copyright please contact us at:

repository@maastrichtuniversity.nl

providing details and we will investigate your claim.
}

Copyright and moral rights for the publications made accessible in the public portal are retained by the authors and/or other copyright owners and it is a condition of accessing publications that users recognise and abide by the legal requirements associated with these

- Users may download and print one copy of any publication from the public portal for the purpose of private study or research.

- You may not further distribute the material or use it for any profit-making activity or commercial gain

If the publication is distributed under the terms of Article $25 \mathrm{fa}$ of the Dutch Copyright Act, indicated by the "Taverne" license above, 


\section{DE ARBEIDSMARKT VOOR TECHNISCH OPGELEIDEN}

- HAALBAARHEIDSONDERZOEK -

ROA-R-1993/12

E.J.T.A. Willems

RESEARCHCENTRUM VOOR ONDERWIJS EN ARBEIDSMARKT

Faculteit der Economische Wetenschappen

Rijksuniversiteit Limburg

Maastricht, december 1993 


\section{CIP-GEGEVENS KONINKLIJKE BIBLIOTHEEK, DEN HAAG}

Willems, E.J.T.A.

De arbeidsmarkt voor technisch opgeleiden: haalbaarheidsonderzoek / E.J.T.A. Willems. Maastricht: Researchcentrum voor Onderwijs en Arbeidsmarkt, Faculteit der Economische Wetenschappen, Rijksuniversiteit Limburg. - Tab. - ([Rapport] / Researchcentrum voor Onderwijs en Arbeidsmarkt, ISSN 0922-8098; ROA-R-1993/12)

Met lit. opg.

ISBN 90-5321-119-5

Trefw.: technisch onderwijs en arbeidsmarkt / arbeidsmarkt; technische beroepen. 
INHOUDSOPGAVE

Bladzijde

VERANTWOORDING

1. INLEIDING 1

2. ACTUELE INFORMATIE OVER DE ARBEIDSMARKT VOOR TECHNICI 3

2.1. Inleiding 3

2.2. Data-infrastructuur 3

2.3. Arbeidsmarktgegevens van technisch opgeleiden 5

3. DE HAALBAARHEID VAN ARBEIDSMARKTPROGNOSES VOOR TECHNICI

3.1. Inleiding 14

3.2. Structuur arbeidsmarktprognoses ROA-informatiesysteem $\begin{array}{ll}\text { onderwijs-arbeidsmarkt } & 14\end{array}$

3.3. Arbeidsmarktprognoses voor technisch opgeleiden 16

3.4. Conclusies 24

4. MOGELIJKE AANVULLENDE GEGEVENS 28

4.1. Inleiding 28

4.2. Gegevens met betrekking tot de beroepsbevolking 28

4.3. Gegevens met betrekking tot schoolverlaters en recent afgestudeerden $\quad 29$

$\begin{array}{ll}\text { 5. BESLUIT } & 43\end{array}$

$\begin{array}{ll}\text { LITERATUUR } & 46\end{array}$

BIJLAGEN:
A. TECHNISCHE BEROEPSKLASSEN EN OPLEIDINGSTYPEN IN HET ROA-INFORMATIESYSTEEM ONDERWIJS-ARBEIDSMARKT

B. OPLEIDINGSINDELING TECHNISCH ONDERWIJS 


\section{VERANTWOORDING}

In opdracht van het Ministerie van Onderwijs en Wetenschappen, het Centraal Bestuur voor de Arbeidsvoorziening (CBA) en de Stichting Landelijk Dienstverlenend Centrum voor studie- en beroepskeuzevoorlichting (LDC) heeft het Researchcentrum voor Onderwijs en Arbeidsmarkt (ROA) het informatiesysteem onderwijs-arbeidsmarkt ontwikkeld. In aansiuiting op dat onderzoek, wordt in dit rapport nagegaan of - bij wijze van 'kopstudie' op het huidige informatiesysteem - de arbeidsmarktgegevens voor technisch opgeleiden verder kunnen worden gedifferentieerd. Het onderzoek is uitgevoerd in opdracht van het Ministerie van Economische Zaken, voor wat betreft het hoger onderwijs en het Ministerie van Onderwijs en Wetenschappen, voor wat betreft het middelbaar en het voorbereidend beroepsonderwijs.

De uitvoering van het onderzoek was in handen van drs. E.J.T.A. Willems. De auteur dankt de overige leden van het ROA-projectteam dat de landelijke beroeps- en opleidingsprognoses opstelt, te weten dr. L. Borghans, drs. R.J.P. Dekker, dr. A. de Grip, drs. A.G.M. Matheeuwsen en drs. M.H. Wieling, voor hun bijdragen aan de diverse onderdelen en hun commentaar op een eerdere versie van dit rapport en M.E.C. Reiners voor de assistentie bij de data-analyses. Tot slot wordt een woord van dank gericht aan dhr. P.W. van Voorthuijsen van het Ministerie van Economische Zaken en dhr. H.M. Claassen van het Ministerie van Onderwijs en Wetenschappen voor hun commentaar op de concept-versie van dit rapport. 


\section{INLEIDING}

De arbeidsmarkt voor technici staat nu al weer zeer geruime tijd in de belangstelling. Steeds vaker zijn er geluiden hoorbaar dat er een schrijnend tekort is aan adequaat geschoold technisch personeel. De problematiek strekt zich daarbij uit van tekorten in kwantitatieve zin ("er zijn geen vakmensen te krijgen") tot en met de kwaliteit van de diverse technische opleidingen. Bij dit laatste kan men denken aan reeds in de jaren ' 70 genoemde kreten als "Ze kunnen tegenwoordig geen hamer meer vasthouden", maar ook aan de groeiende ongerustheid over de kwaliteit van de afgestudeerden van de technische universiteiten.

Deze geluiden zijn nogal eens gebaseerd op meningen en ervaringen vanuit werkgeverskringen. Dit is ook logisch, aangezien zij als eerste de gevolgen merken van tekorten aan bepaalde opleidingscategorieën. Dit kan bijvoorbeeld blijken uit het moeilijk vervulbaar zijn van vacatures, uit een hoog verlooppercentage e.d. Voor een adequaat arbeidsmarktbeleid is het echter onvoldoende om alleen op dergelijke geluiden af te gaan. Werkgevers hebben veelal slechts zicht op (een deel van) de vraag naar arbeidskrachten. Bovendien is vaak de termijn waarover men gegevens heeft beperkt. Het is echter van belang om een beeld te krijgen van de totale arbeidsmarkt en de ontwikkelingen daarin. Dit betekent dat niet alleen de verwachte vraagontwikkelingen in kaart moeten worden gebracht, maar dat het tevens noodzakelijk is een analyse te maken van de toekomstige ontwikkelingen aan de aanbodzijde van de markt. Anders dreigt het arbeidsmarktbeleid te verworden tot curatief beleid in plaats van het eigenlijk vereiste preventief beleid (zie De Grip, 1987).

Derhalve is goede informatie over de arbeidsmarkt voor de diverse opleidingscategorieën vereist. Het Researchcentrum voor Onderwijs en Arbeidsmarkt (ROA) heeft voor dat doel het informatiesysteem onderwijs-arbeidsmarkt ontwikkeld, waarin een groot aantal arbeidsmarktgegevens wordt verzameld (zie ROA, 1993a en 1993b). De informatie wordt daarbij in drie hoofdcategorieën ingedeeld:

- actuele informatie en trendmatige ontwikkelingen in het recente verleden;

- arbeidsmarktindicatoren die het risico van een bepaalde opleidingskeuze aangeven;

- middellange-termijn arbeidsmarktprognoses.

De informatie heeft daarbij betrekking op in totaal ongeveer 90 beroepsklassen en 50 opleidingstypen, verdeeld over de volle breedte van de arbeidsmarkt.

Momenteel worden in het ROA-informatiesysteem 35 technische beroepen onderscheiden, 23 beroepen op lager niveau, 8 beroepen op middelbaar niveau en 4 beroepen op hoger niveau. Daarnaast worden 7 opleidingstypen tot de technische ${ }^{1}$ opleidingen gerekend: én opleiding van het Voorbereidend Beroepsonderwijs $(\mathrm{VBO})^{2}$, twee opleidingen van het Middelbaar Beroepsonderwijs (MBO), twee studierichtingen in het Hoger Beroepsonderwijs (HBO) en

1. In dit rapport worden ook de bèta-richtingen tot het technisch onderwijs gerekend.

2. Sinds 1 augustus 1992 is het VBO in de plaats gekomen van het lager beroepsonderwijs (LBO). 
eveneens twee studierichtingen in het Wetenschappelijk Onderwijs (WO). In bijlage A wordt een overzicht gegeven van deze technische beroepen en technische opleidingen.

Voor zowel het voeren van een deugdelijk arbeidsmarktbeleid, als voor de studie- en beroepskeuzevoorlichting is het aggregatieniveau waarop de gegevens momenteel beschikbaar zijn vooral voor de technische opleidingen vrij hoog. Binnen de onderscheiden categorieën gaat het echter vaak om verschillende zeer specifieke opleidingsgebieden. Op dit moment wordt bijvoorbeeld geen onderscheid gemaakt tussen de opleidingsrichtingen elektrotechniek en werktuigbouwkunde. Dit betekent derhalve dat de mogelijke verschillen in de arbeidsmarktpositie tussen de beide opleidingscategorieën op dit moment met behulp van het informatiesysteem niet kunnen worden achterhaald.

In dit rapport zal worden nagegaan of en in hoeverre het mogelijk is de gegevens van het ROAinformatiesysteem te differentiëren naar meer (onderliggende) richtingen van het technisch onderwijs. Daarbij zal zowel worden ingegaan op de actuele informatie en de risico-indicatoren als op het opstellen van middellange-termijn prognoses. Bovendien zal worden bekeken of er mogelijke andere databronnen zijn op basis waarvan arbeidsmarktgegevens met betrekking tot technisch opgeleiden kunnen worden gepresenteerd.

De opzet van dit rapport is als volgt. In hoofdstuk 2 worden enkele actuele arbeidsmarktgegevens over technisch opgeleiden gepresenteerd. Hoofdstuk 3 gaat vervolgens in op de mogelijkheid specifieke prognoses voor technisch opgeleiden op te stellen op een vrij gedesaggregeerd niveau. De mogelijkheid tot het inpassen van andere arbeidsmarktgegevens in een eventueel arbeidsmarktinformatiesysteem voor technisch opgeleiden komt aan de orde in hoofdstuk 4. In hoofdstuk 5 wordt het rapport tenslotte samengevat en afgesloten met enkele conclusies en suggesties voor nader onderzoek. 


\section{ACTUELE INFORMATIE OVER DE ARBEIDSMARKT VOOR TECHNICI}

\subsection{Inleiding}

In dit hoofdstuk zullen enkele actuele gegevens met betrekking tot de arbeidsmarkt voor technisch opgeleiden worden gepresenteerd. Uitgangspunt daarbij is het soort informatie dat momenteel in het informatiesysteem onderwijs-arbeidsmarkt van het ROA is opgenomen. Daarbij wordt uitsluitend ingegaan op de gegevens per opleidingstype; gegevens per beroepsklasse blijven verder buiten beschouwing.

De verdere opzet van dit hoofdstuk is als volgt. In paragraaf 2.2. zal eerst worden ingegaan op de data-infrastructuur. Paragraaf 2.3. geeft vervolgens een overzicht van enkele arbeidsmarktgegevens met betrekking tot de arbeidsmarkt voor technisch opgeleiden.

\subsection{Data-infrastructuur}

De actuele gegevens en arbeidsmarktindicatoren die op dit moment in het informatiesysteem onderwijs-arbeidsmarkt zijn opgenomen, zijn vrijwel allemaal gebaseerd op de Enquête Beroepsbevolking (EBB) van het Centraal Bureau voor de Statistiek (CBS). De EBB is een doorlopende enquête, die sinds 1987 wordt gehouden. De totale jaarlijkse steekproef bedraagt ongeveer 120.000-130.000 adressen. Het aantal geënquêteerde personen van 15-64 jaar is jaarlijks circa 100.000 tot 110.000 . Dit komt overeen met een steekproeffractie van ruim $1 \%$.

In de $E B B$ is een groot aantal gegevens betreffende de positie van de bevolking op de arbeidsmarkt opgenomen. Dit betreft onder meer:

- demografische kenmerken (geslacht, leeftijd, nationaliteit);

- voornaamste bezigheid (werkzaam, scholier/student enz.);

- gevolgde opleiding;

- bedrijfsklasse waarin men werkt;

- beroep dat men uitoefent;

- arbeidsduur;

- het al dan niet op zoek zijn naar werk.

De belangrijkste resultaten van de enquête worden jaarlijks gepubliceerd ${ }^{3}$. Daarbij zijn de steekproefuitkomsten opgehoogd tot de 'werkelijke' aantallen.

Naast de gepubliceerde gegevens kan het ROA op basis van een overeenkomst met het CBS tevens gebruik maken van de achterliggende niet-gepubliceerde data. Voorwaarde daarbij is wel dat alleen gegevens worden gepubliceerd over categorieën met tenminste 5.000 werkenden,

3. Zie voor de meest recente publikatie CBS (1993). 
waarbij tevens een afronding plaatsvindt op 1.000-tallen ${ }^{4}$. Dit is overeenkomstig de werkwijze zoals het CBS die in haar publikaties hanteert. Deze publikatierestricties vloeien enerzijds voort uit het feit dat individuele respondenten niet herkenbaar mogen zijn in de gegevens en anderzijds uit de eisen van nauwkeurigheid van de uitkomsten.

In de EBB-publikatie zijn de $95 \%$-betrouwbaarheidsmarges van de uitkomsten gepresenteerd. Tabel 2.1 geeft de absolute en relatieve marges die bij de (opgehoogde) aantallen in acht moeten worden genomen. Vooral bij kleine aantallen zijn de marges relatief groot. Zo blijkt uit de tabel dat bij een gepresenteerd aantal van 5.000 slechts kan worden gezegd dat dit aantal met $95 \%$ betrouwbaarheid in het interval 3.500 tot 6.500 ligt. Daarnaast moet worden bedacht dat behalve als gevolg van steekproeffouten er ook afwijkingen kunnen optreden, die zijn veroorzaakt door meetfouten, fouten in het steekproefkader, fouten als gevolg van selectiviteit in de non-respons en verwerkingsfouten (zie verder CBS, 1993).

Tabel 2.1. Betrouwbaarheidsmarges van de opgehoogde EBB-aantallen $1992(95 \%)$

\begin{tabular}{rrr}
\hline $\begin{array}{c}\text { Opgehoogde } \\
\text { aantallen }\end{array}$ & abs. & marges \\
\hline 5.000 & & $\%$ \\
10.000 & 1.500 & 30,0 \\
15.000 & 2.100 & 21,2 \\
20.000 & 2.600 & 17,3 \\
30.000 & 3.000 & 15,0 \\
50.000 & 3.700 & 12,2 \\
75.000 & 4.700 & 9,5 \\
100.000 & 5.800 & 7,7 \\
200.000 & 6.700 & 6,7 \\
300.000 & 9.400 & 4,7 \\
500.000 & 11.500 & 3,8 \\
750.000 & 14.600 & 2,9 \\
$1,000.000$ & 17.700 & 2,4 \\
$2,000.000$ & 20.200 & 2,0 \\
$3,000.000$ & 26.900 & 1,3 \\
$5,000.000$ & 30.900 & 1,0 \\
$7,500.000$ & 33.800 & 0,7 \\
\hline
\end{tabular}

Bron: CBS (1993)

Op basis van de $E B B$ is vooralsnog geen gedetailleerde informatie beschikbaar over de werkloosheid. Wel waren tot april 1991 op basis van het ISVA-bestand IInformatieSysteem Vraag Aanbod) van de Arbeidsvoorzieningsorganisatie werkloosheidsgegevens beschikbaar, gebaseerd op het aantal ingeschrevenen bij de Arbeidsbureaus (zie ook Wieling, Dekker en De Grip, 1991). Een probleem bij deze data is echter de redelijk grote mate van de bestandsvervuiling en de

4. Deze restricties gelden bij het gebruik van jaarcijfers. Indien gebruik wordt gemaakt van driejaarsgemiddelden geldt een ondergrens van 2.000, terwijl afronding op 500-tallen kan plaatsvinden. 
soms tekortschietende codering van de opleidingsgegevens. Momenteel wordt door de Arbeidsvoorzieningsorganisatie gewerkt aan een nieuwe database voor (onder meer) werkloosheidsgegevens. Dit betreft het zogenaamde Primair Gemeenschappelijk Informatiesysteem (PGI). Het zal nog zeker tot het voorjaar van 1994 duren voordat de PGI-cijfers extern beschikbaar komen.

Daarnaast worden onder verantwoordelijkheid van het ROA momenteel twee grootschalige enquête-onderzoeken uitgevoerd die tevens een belangrijke gegevensbron voor het informatiesysteem kunnen vormen. Het gaat om schriftelijke enquêtes onder schoolverlaters, ongeveer een jaar nadat deze de opleiding hebben verlaten. De eerste enquête betreft de Registratie Uitstroom en Bestemming van Schoolverlaters (RUBS) (zie voor de meest recente publikaties Wieling, Van de Loo en Van der Velden, 1993a en 1993b). De enquête heeft daarbij betrekking op schoolverlaters van het algemeen voortgezet onderwijs, het VBO en het MBO. De tweede enquete is de HBO-Monitor, die wordt gehouden onder de afgestudeerden van het HBO (zie Van de Loo, Van der Velden en Wieling, 1993).

Zowel de RUBS-enquête als de HBO-Monitor zijn qua respons redelijk verdeeld naar opleidingsrichting. Dit maakt het mogelijk om op een vrij gedetailleerd niveau van opleidingen betrouwbare schoolverlatersinformatie te verstrekken. Helaas is het echter vooralsnog niet mogelijk om voor alle opleidingen vergelijkbare informatie te verstrekken, omdat er geen gegevens beschikbaar zijn over de schoolverlaters van het basisonderwijs en met name het wetenschappelijk onderwijs.

Recent is door het ROA een onderzoek afgerond naar de inpassing van de RUBS- en HBOMonitor-data in het ROA-informatiesysteem (De Grip, Van der Velden en Wieling, 1993a). Een belangrijke conclusie uit dit onderzoek is dat enkele conceptuele en praktische problemen die momenteel met het gebruiken van voornamelijk EBB-gegevens in het informatiesysteem optreden, met behulp van de schoolveriatersgegevens kunnen worden opgelost. Dit betreft onder meer het feit dat een aantal actuele arbeidsmarktgegevens en -indicatoren op een veel gedetailleerder niveau kunnen worden gepresenteerd, mede samenhangend met het feit dat veel minder stringente ondergrenzen bij de publikatie van deze gegevens worden gehanteerd. Daarnaast kan bijvoorbeeld meer betrouwbare informatie worden gegeven over de mate van onderbenutting. Ook ten aanzien van de werkloosheid leveren de schoolverlatersenquêtes belangrijke informatie op. In de meest recente versie van het informatiesysteem onderwijsarbeidsmarkt wordt reeds gebruik gemaakt van RUBS- en HBO-Monitor-gegevens met betrekking tot de werkloosheid onder schoolverlaters.

\subsection{Arbeidsmarktgegevens van technisch opgeleiden}

Tabel 2.2 geeft een overzicht van de actuele arbeidsmarktgegevens en -indicatoren per opleidingstype die momenteel in het ROA-informatiesysteem onderwijs-arbeidsmarkt zijn opgenomen. In de tabel is tevens aangegeven wat de bron van de gegevens is en op welke manier de data door het ROA zijn gepubliceerd: via de jaarlijks te actualiseren Statistische bijlage bij het tweejaarlijkse ROA-rapport De arbeidsmarkt naar opleiding en beroep (zie ROA. 
1993b) en/of via de multifunctionele database voor studie- en beroepskeuzevoorlichting, die wordt beheerd door het door het Landelijk Dienstverlenend Centrum voor studie- en beroepskeuzevoorlichting (LDC). Op basis van deze database wordt onder meer het geautomatiseerde systeem Traject samengesteld ${ }^{⿷}$.

Tabel 2.2. Overzicht van actuele data en arbeidsmarktindicatoren in het ROA-informatiesysteem onderwijs-arbeidsmarkt

aantal werkenden en percentage in totale werkgelegenheid

verhouding man/vrouw

belangrijkste beroepsklassen

belangrijkste beroepsgroepen

werkloosheid

werkloosheid onder schoolverlaters

percentage onderbenutting

beroepenspreiding

bedrijfssectorspreiding

$\begin{array}{ll}\text { EBB } & 1,2 \\ \text { EBB } & 1 \\ \text { EBB } & 2 \\ \text { EBB } & 2\end{array}$

(momenteel niet beschikbaar)

RUBS/HBO-Monitor 2

EBB/ROA 1

EBB/ROA 1,2

EBB/ROA $\quad 1,2$

1 = opgenomen in ROA (1993b)

2 = opgenomen in de multifunctionele database van het LDC (aanlevering 1993)

Zoals reeds aangegeven in de inleiding van dit rapport, worden momenteel in het informatiesysteem 7 opleidingstypen - verdeeld over vier niveaus - in de technische richting onderscheiden. Zowel voor het voeren van arbeidsmarktbeleid als voor degenen die een keuze voor studie of beroep moeten maken, is een dergelijke indeling veelal onvoldoende gedetailleerd. Op basis van de meest recente EBB (1992) zijn daarom enkele gegevens op een lager aggregatieniveau verzameld, zodat de onderliggende opleidingsrichtingen binnen de technische richting kunnen worden onderscheiden.

In tabel 2.3 is het aantal werkenden met een technische opleidingsachtergrond gepresenteerd, waarbij een verbijzondering is gemaakt naar opleidingsniveau en -richting ${ }^{6}$. Daarbij zijn de opleidingstypen die momenteel reeds in het informatiesysteem worden onderscheiden vet gedrukt.

In totaal zijn er in Nederland momenteel ongeveer 1,4 miljoen werkenden die een technische opleiding hebben gevolgd. Daarvan hebben ongeveer 38.000 mensen een academische opleiding in de wis- en natuurkunde gevolgd. Circa 55.000 arbeidskrachten zijn afgestudeerd in de technische richting op wetenschappelijk niveau. Binnen dit opleidingstype is de richting

5. Dit is de voortzetting van het /-See/-systeem. Voorlopig bevat Traject alleen gegevens over het hoger onderwijs. Voor de inhoud van de arbeidsmarktmodule van I-See! 1991 wordt verwezen naar Dekker, De Grip, Berendsen, Wieling en Willems (1992).

6. In bijlage $B$ is aangegeven welke opleidingsrichtingen tot de in de tabel opgenomen typen worden gerekend. Daarbij is tevens de codering volgens de Standaard Onderwijs Indeling (SOI) 1978 opgenomen. 
bouwkunde het grootste. Werktuigbouwkunde en elektrotechniek zijn daarentegen relatief kleine opleidingsrichtingen.

Tabel 2.3. Aantal werkende technisch opgeleiden naar opleidingsniveau en -richting 1992

Opleidingsniveau en -richting

aantal werkenden

Wetenschappelijk onderwijs

Wis- en natuurkunde

38.000

Technisch

55.000

bouwkunde

19.000

werktuigbouwkunde

9.000

elektrotechniek

9.000

overig

18.000

Hoger beroepsonderwijs

Technisch laboratorium

Technisch

123.000

bouwkunde

33.000

werktuigbouwkunde

31.000

elektrotechniek

40.000

overig

19.000

Middelbaar beroepsonderwijs

Technisch laboratorium

Technisch

691.000

bouwkunde

145.000

weg- en waterbouwkunde

22.000

metaalkunde

63.000

fijnmechanısche techniek

14.000

werktuigbouwkunde

89.000

motorvoertugentechniek

62.000

elektrotechniek

148.000

procestechniek

17.000

overig

132.000

Voorbereidend beroepsonderwijs

Technisch

499.000

bouwtechniek

137.000

installatie techniek

10.000

metaalkunde

140.000

werktuigbouwkunde

6.000

motorvoertuigentechniek

47.000

elektrotechniek

64.000

grafische techniek

10.000

consumptieve techniek

29.000

overig

56.000

Bron: CBS/ROA 
Circa 150.000 werkenden hebben een hogere beroepsopleiding in de technische richting als opleidingsachtergrond. Bijna $20 \%$ hiervan heeft een technische laboratoriumopleiding gevolgd. Van de overige hoger technisch opgeleiden vormt de richting elektrotechniek met 40.000 werkenden de grootste categorie. Ook de richtingen bouwkunde en werktuigbouwkunde zijn met allebei ruim 30.000 werkenden redelijk groot.

Het $M B O$ is met in totaal ruim 2 miljoen werkenden de belangrijkste opleidingscategorie in Nederland (zie bijvoorbeeld ROA, 1993b). In de loop van de jaren ' 80 is er volgens De Grip en Dekker (1993) sprake geweest van een enorme toename van het aantal arbeidskrachten met een opleiding op MBO-niveau. Zij typeren deze periode daarom als het decennium van de MBOisering van de vakarbeid. Binnen het $M B O$ behoort het technisch onderwijs - samen met het economisch-administratief onderwijs - tot de grootste hoofdrichtingen. In totaal hebben ongeveer 700.000 werkenden een technische opleidingsachtergrond op MBO-niveau. Bouwkunde en elektrotechniek vormen binnen het middelbaar technisch onderwijs (MTO) de grootste categorieën. Ook de richting werktuigbouwkunde is met circa 90.000 werkenden vrij groot. Daarnaast hebben ruim 60.000 werkenden een MTO-opleiding in de richting metaalkunde gevolgd. Ongeveer evenveel arbeidskrachten hebben MTO motorvoertuigentechniek als opleidingsachtergrond. Het aantal werkenden met een opleiding in de richtingen fijnmechanische techniek of procestechniek is vrij klein.

Circa 500.000 werkenden hebben een technische opleiding in het voorbereidend beroepsonderwijs als hoogste afgeronde opleiding. De technische richting is daarmee duidelijk de grootste van het gehele $V B O$. Binnen het voorbereidend technisch onderwijs zijn de richtingen bouwtechniek en metaalkunde het belangrijkste. Het aantal werkenden met een dergelijke opleidingsachtergrond is voor beide richtingen ongeveer 140.000. De richtingen motorvoertuigentechniek en elektrotechniek zijn op dit niveau ook redelijk groot, maar de richtingen installatietechniek, werktuigbouwkunde en grafische techniek behoren tot de kleinere richtingen.

In tabel 2.4 is de man/vrouw-verhouding van de werkende technici weergegeven. Onmiddellijk blijkt dat het aandeel van vrouwen in de meeste technische richtingen erg klein is. Voor vrijwel alle richtingen geldt dat hierin minder dan 5.000 vrouwen werkzaam zijn, hetgeen zoals reeds aangegeven, bij het CBS als minimum geldt voor de publikatie van EBB-cijfers. In totaal zijn er circa 95.000 vrouwen met een technische opleidingsachtergrond werkzaam. Van hen hebben er ruim 25.000 een opleiding op VBO-niveau, bijna 50.000 een MBO-opleiding en de overige 20.000 hebben een opleiding op HBO- of academisch niveau afgerond. Hierbij moet wel worden opgemerkt dat meer dan de helft van alle vrouwelijke technici een opleiding uit de categorie 'overig' heeft gevolgd. Dit betreft onder meer de opleidingen voedingsmiddelentechniek, chemische techniek, textiel- en leerverwerking e.d. 
Tabel 2.4. Man/vrouw-verhouding van de werkende technisch opgeleiden naar opleidingsniveau en -richting 1992

Opleidingsniveau en -richting

mannen vrouwen

$\% \quad \%$

Wetenschappelijk onderwijs

Wis- en natuurkunde

Technisch

bouwkunde

werktuigbouwkunde

100

elektrotechniek

overig

Hoger beroepsonderwijs

Technisch laboratorium

Technisch

bouwkunde

werktuigbouwkunde

elektrotechniek

overig

Middelbaar beroepsonderwijs

Technisch laboratorium

Technisch

bouwkunde

weg- en waterbouwkunde

fijnmechanische techniek

werktuigbouwkunde

motorvoertuigentechniek

elektrotechniek

procestechniek

overig

Voorbereidend beroepsonderwijs

Technisch

$94 \quad 6$

bouwtechniek

installatietechniek

metaalkunde

werktuigbouwkunde

motorvoertuigentechniek

elektrotechniek

grafische techniek

consumptieve techniek

overig

\section{Bron: $\mathrm{CBS} / \mathrm{ROA}$}

In de in bijlage C weergegeven tabel C. 1 wordt een overzicht gegeven van de belangrijkste bedrijfssectoren waarin de technisch opgeleiden werkzaam zijn. Daarnaast geeft tabel C.2 een 
beeld van de belangrijkste beroepsklassen ${ }^{7}$ van de werkende technisch opgeleiden. Van de academisch opgeleide technici is bij slechts twee opleidingsrichtingen een bedrijfssector waarin men werkzaam is bekend. Van de afgestudeerden in de wis- en natuurkunde werkt ruim een derde in de sector 'Onderwijs'. Bijna de helft van de bouwkundigen op academisch niveau is werkzaam in de 'Overige commerciële dienstverlening'. De wis- en natuurkundigen zijn vooral werkzaam in de beroepsklassen 'Docenten voortgezet en hoger onderwijs', 'Bèta-onderzoekers en technische vakspecialisten' en 'Systeemanalisten, -programmeurs en -beheerders'. Het wekt geen verbazing dat degenen met een opleiding bouwkunde vooral werkzaam zijn in de beroepsklasse 'Architecten, geodeten e.a. hogere bouwkundigen'.

Op HBO-niveau is meer informatie beschikbaar over de bedrijfssectoren en de beroepsklassen waarin men werkzaam is ${ }^{8}$. De belangrijkste bedrijfssector voor de bouwkundigen op HBOniveau is, evenals op WO-niveau, de 'Overige commerciële dienstverlening'. Van de werktuigbouwkundige HBO-ers is bijna een kwart werkzaam in de 'Metaalindustrie' Voor HBO elektrotechniek is de 'Elektrotechnische industrie' de belangrijkste bedrijfssector. Opvallend is dat de beroepsklasse waarin de meeste HBO-ers bouwkunde werkzaam zijn de beroepsklasse 'Leidinggevenden produktie, bedrijfskundigen en directeuren' is. Ook van de werktuigbouwkundigen en de elektrotechnici is een aanzienilijk deel in deze beroepsklasse werkzaam. Blijkbaar komt een relatief groot deel van de technici uiteindelijk in management-achtige functies terecht. Van de HBO-ers elektrotechniek is overigens een groot gedeelte werkzaam als systeemanalist, -programmeur of -beheerder.

De belangrijkste bedrijfssector voor de bouwkundigen op MBO-niveau is vanzelfsprekend de sector 'Bouw'. lets meer dan de helft van de arbeidskrachten met deze opleidingsachtergrond is in deze sector werkzaam. Voor het overige zijn de werkenden over verscheidene sectoren verdeeld. De belangrijkste daarvan is de 'Overige commerciële dienstverlening', waar ongeveer $10 \%$ van de arbeidskrachten werkzaam is. Voor de MBO-ers metaalkunde is de 'Metaalindustrie' met cırca $45 \%$ van de werkgelegenheid de belangrijkste bedrijfssector. De werktuigbouwkundigen zijn echter over een groot aantal bedrijfssectoren verspreid. De 'Metaalindustrie' is hiervan met een werkgelegenheidsaandeel van ruim $20 \%$ het grootst. Degenen die een opleiding MBO motorvoertuigentechniek hebben gevolgd zijn vooral werkzaam in de 'Overige commerciële dienstverlening'. Voor de MBO-ers elektrotechniek zijn de 'Bouw' en de 'Handel' de belangrijkste bedrijfssectoren. Overigens zijn de elektrotechnici evenals de werktuigbouwkundigen in zeer veel verschillende sectoren werkzaam.

De belangrijkste beroepsklasse voor de MBO-ers bouwkunde is 'Timmerlieden e.a. houtbewerkers'. In deze beroepsklasse is ongeveer een kwart van de arbeidskrachten werkzaam. Ook de beroepsklasse 'Leidinggevenden produktie, bedrijfskundigen en directeuren'

7. Daarbij is gebruik gemaakt van de ROA-beroepsklassen (zie Van de Loo, Dekker en De Grip, 1992). Wel zijn de beroepsklassebenamingen enigszins aangepast (zie ook ROA, 1993a).

8. Hier zal slechts worden ingegaan op de voor de desbetreffende opleidingsrichting belangrijkste bedrijfssector(en) en wordt dus geen uitputtende beschrijving gegeven. 
is met ongeveer $15 \%$ van de werkgelegenheid opvallend groot. Degenen die het diploma MBO metaalkunde hebben behaald, zijn, zoals mocht worden verwacht, vooral werkzaam in de metaalberoepen, zoals 'Lassers en constructiewerkers' (17\%) en 'Machinebank-, plaatwerkers en gereedschapsmakers' $(22 \%)$. Van de werktuigbouwkundigen is een belangrijk deel werkzaam in een leidinggevende functie in de produktie. Daarnaast is een groot deel werkzaam in de beroepsklasse 'Onderhoudsmonteurs, fietsen- en instrumentmakers'. Niet verrassend is dat de grootste beroepsklasse voor MBO motorvoertuigentechniek 'Automonteurs en (motor)rijwielherstellers' is. In deze beroepsklasse is echter nog geen derde deel van de arbeidskrachten met de desbetreffende opleidingsachtergrond werkzaam. Van alle werkzame MBO-ers elektrotechniek is ruim een derde werkzaam als 'Elektriciens, elektro- en telecom(onderhouds)monteurs'. Ook van deze opleidingscategorie is echter een aanzienlijk deel werkzaam in de beroepsklasse 'Leidinggevenden produktie, bedrijfskundigen en directeuren'.

Bij het VBO bouwtechniek is de belangrijkste bedrijfssector vanzelfsprekend de 'Bouw', terwijl de 'Metaalindustrie' het belangrijkste is voor VBO metaalkunde. Bij deze laatste opleidingscategorie is ook een aanzienlijk deel van de arbeidskrachten werkzaam in de bedrijfssectoren 'Bouw', 'Handel' en 'Vervoer en communicatie'. De VBO-ers elektrotechniek zijn evenals de MBO-opgeleiden in deze richting over een groot aantal sectoren verspreid. De belangrijkste daarvan is de 'Bouw'. Slechts een beperkt deel (nog geen 10\%) werkt in de 'Elektrotechnische industrie'.

Evenals voor MBO bouwkunde is ook voor VBO bouwtechniek de beroepsklasse 'Timmerlieden e.a. houtbewerkers' het belangrijkste. Andere belangrijke, maar tevens voor de hand liggende beroepsklassen zijn 'Metselaars, tegelzetters, straatmakers en stukadoors' en 'Huis. en constructieschilders'. De VBO-ers metaalkunde zijn over tal van beroepsklassen verspreid. De belangrijkste daarvan zijn 'Lassers en constructiewerkers', 'Machinebank-, plaatwerkers en gereedschapsmakers' en, opvallend genoeg, 'Chauffeurs en spoorwegpersoneel'. Ook van de VBO-ers motorvoertuigentechniek is een belangrijk deel in deze laatstgenoemde beroepsklasse werkzaam. Daarnaast is voor deze opleidingscategorie vanzelfsprekend de beroepsklasse 'Automonteurs en (motor)rijwielherstellers' belangrijk. Zoals mocht worden verwacht, zijn voor de opleidingsrichtingen VBO elektrotechniek en VBO grafische techniek respectievelijk de beroepsklassen 'Elektriciens, elektro- en telecom(onderhouds/monteurs' en 'Drukkers en produktiepersoneel grafische industrie' het belangrijkst. Degenen die een opleiding VBO consumptieve techniek hebben gevolgd, zijn in verscheidene beroepsklassen werkzaam, waarvan de beroepsklasse 'Bakkers en (industrieel) bakkerijpersoneel' de belangrijkste is.

Op basis van deze gegevens kan worden geconcludeerd dat vooral op $\mathrm{HBO}$ - en WO-niveau de technici over tal van bedrijfssectoren en beroepen zijn verspreid. Voor technici met een VBO- of een MBO-opleiding is de relatie met de bedrijfssector waarin men terechtkomt echter veel duidelijker. Verder is het opvallend dat een groot deel van de werkenden in de beroepsklasse 'Leidinggevenden produktie, bedrijfskundigen en directeuren' terechtkomt, al moet daarbij worden beseft dat dit een erg breed gedefinieerde beroepsklasse betreft. 
Tabel 2.5. Werkloosheid onder technisch opgeleiden naar opleidingsniveau en -richting april 1991 (bemiddelingsbestand zonder baan), aantallen en gerelateerd aan aantal werkenden 1992

Opleidingsniveau en -richting

aantal

1991 t.o.v. aantal

werkenden 1992

$\%$

Wetenschappelijk onderwijs

Wis- en natuurkunde

Technisch

bouwkunde

werktuigbouwkunde

elektrotechniek

overig

Hoger beroepsonderwijs

Technisch laboratorium

Technisch

bouwkunde

werktuigbouwkunde

elektrotechniek

overig

Middelbaar beroepsonderwijs

Technisch laboratorium

Technisch

bouwkunde

weg-en waterbouwkunde

metaalkunde

fijnmechanische techniek

werktuigbouwkunde

motorvoertuigentechniek

elektrotechniek

procestechniek

overig

Voorbereidend beroepsonderwijs

Technisch

bouwtechniek

installatietechniek

metaalkunde

werktuigbouwkunde

motorvoertuigentechniek

elektrotechniek

grafische techniek

consumptieve techniek

overig
100

0

800

200

200

100

100

100

1.700

400

400

600

300

300

3

5.500

900

300

100

500

1.100

200

1.400

100

1.000

4

1

1

1

2

2
46.600

15.400

1.000

13.600

100

4.600

5.300

900

2.400

3.100
9

11

10

10

17

10

8

9

8

5

Bron: Arbeidsvaorzieningsorganisatie/ROA 
Eén van de belangrijkste arbeidsmarktgegevens is vanzelfsprekend de omvang van de werkloosheid. Helaas zijn momenteel geen gedesaggregeerde gegevens over de geregistreerde werkloosheid beschikbaar, maar is de informatie beperkt tot de werkloosheid per opleidingsniveau. Tot voor enkele jaren werden echter, zoals reeds opgemerkt in paragraaf 2.2, wel via de Arbeidsbureaus gegevens verzameld. Het grote nadeel van deze gegevens was echter de grote mate van bestandsvervuiling (zie bijvoorbeeld Detmar en Dekker, 1987). Ook schiet de opleidingscodering van deze gegevens te kort (zie Wieling, Dekker en De Grip, 1991). Op dit moment worden de gegevens mede vanwege deze redenen niet meer verstrekt. De laatst beschikbare gedesaggreggeerde werkloosheidsgegevens hebben betrekking op april 1991 en zijn gebaseerd op de registratiebestanden van de Arbeidsvoorzieningsorganisatie ${ }^{9}$.

Tabel 2.5 geeft een overzicht van de werkloosheid onder technisch opgeleiden, verbijzonderd naar opleidingsniveau en -richting. Om enig inzicht te krijgen in de relatieve omvang van de werkloosheid zijn deze gegevens gerelateerd aan de werkgelegenheid in 1992, als vermeld in tabel 2.3 van dit rapport. Daarbij wordt benadrukt dat het weergegeven percentage niet kan worden gezien als een 'werkloosheidspercentage', maar slechts wordt gepresenteerd om de interpretatie van de weergegeven aantallen te vergemakkelijken. Bovendien moet worden beseft dat eventuele verschillen op basis van de gepresenteerde percentages mogelijk worden overschat. Indien immers een hoge werkloosheid samenhangt met een krimpende werkgelegenheid voor de desbetreffende opleidingscategorie is door de relatering aan een kleiner aantal werkenden het in de tabel weergegeven percentage hoger, terwijl voor groeiende opleidingen het percentage juist kleiner is.

Ondanks de gebrekkigheid van de werkloosheidsgegevens in tabel 2.5, blijkt heel duidelijk dat vooral op VBO-niveau sprake is van een redelijk grote werkloosheid. Voor de technisch opgeleiden op de drie andere niveaus is de werkloosheid in 1991 relatief laag. Tussen de verschillende richtingen is het verschil vrij gering. Opvallend is wel dat de werkloosheid voor de laboratoriumrichtingen iets hoger is. Op MBO-niveau kent verder de richting fijnmechanische techniek een iets hogere werkloosheid. Op VBO-niveau is de werkloosheid het hoogst voor de hele kleine richting werktuigbouwkunde. Ook bij de richting bouwtechniek is de werkloosheid hoger dan voor de andere richtingen op VBO-niveau.

9. Wel zijn er op basis van RUBS-enquete en de HBO-Monitor gegevens over de werkloosheid onder schoolverlaters bekend. In hoofdstuk 4 wordt uitgebreider op deze RUBS- en HBO-Monitor-gegevens ingegaan. 


\section{DE HAALBAARHEID VAN ARBEIDSMARKTPROGNOSES VOOR TECHNICI}

\subsection{Inleiding}

Nadat in het vorige hoofdstuk is ingegaan op enkele gedetailleerde actuele arbeidsmarktgegevens voor technici, zal in dit hoofdstuk worden nagegaan of het mogelijk is om middellange-termijn arbeidsmarktprognoses op een dergelijk gedetailleerd niveau op te stellen. Uitgangspunt daarbij is de methodiek die door het ROA voor het opstellen van de prognoses in het kader van het informatiesysteem onderwijs-arbeidsmarkt wordt gehanteerd. Daarbij wordt uitgegaan van de methodiek die is gebruikt voor de nieuwste prognoses die recentelijk gereed zijn gekomen. Deze prognoses hebben betrekking op de periode 1993-1998 ${ }^{10}$.

Dit hoofdstuk is verder als volgt opgebouwd. Eerst wordt in paragraaf 3.2 de prognosemethodiek van het informatiesysteem kort toegelicht. In paragraaf 3.3 wordt vervolgens ingegaan op de haalbaarheid van prognoses van de arbeidsmarkt voor technisch opgeleiden verdeeld naar subrichting. De conclusies van dit hoofdstuk zullen tenslotte worden weergegeven in paragraaf 3.4 .

\subsection{Structuur arbeidsmarktprognoses ROA-informatiesysteem onderwijs-arbeidsmarkt}

Voor het opstellen van arbeidsmarktprognoses is in het informatiesysteem onderwijsarbeidsmarkt van het ROA gekozen voor een 'stroomcijfer'-aanpak, waarbij de prognoses worden opgesteld voor een bepaalde toekomstige periode en dus niet voor een bepaald toekomstig tijdstip (zie ROA, 1993a). Een dergelijke aanpak heeft als voordeel dat de verschillende onderliggende vraag- en aanbodontwikkelingen, zoals die zich naar verwachting over de gehele prognoseperiode genomen zullen voordoen, in beeld kunnen worden gebracht. De prognoses hebben daarbij betrekking op beroepen en opleidingen verdeeld over de volle breedte van de arbeidsmarkt.

In figuur 3.1 is de prognosemethodiek schematisch weergegeven. Aan de vraagzijde van de arbeidsmarkt wordt een onderscheid gemaakt tussen de uitbreidingsvraag als gevolg van een positieve ontwikkeling van de werkgelegenheid voor een bepaalde beroepsklasse of een bepaald opleidingstype en de vervangingsvraag vanwege pensionering, arbeidsongeschiktheid, al dan niet tijdelijke terugtrekking van de arbeidsmarkt, beroepsmobiliteit e.d. De verwachte uitbreidingsvraag en vervangingsvraag vormen samen de prognose voor het toekomstig aantal baanopeningen in de prognoseperiode. Tegenover deze totale vraag staat het verwachte aanbod van nieuwkomers op de arbeidsmarkt. Hierbij kan een onderverdeling worden gemaakt naar de toekomstige instroom van schoo/verlaters en het aanbod van (kortdurig) werk/ozen.

10. Deze prognoses zijn onlangs gepubliceerd middels het rapport De arbeidsmarkt naar opleiding en beroep tot 1998 (ROA, 1993a). Daarnaast zijn de gegevens aangeleverd aan het LDC. 
Figuur 3.1. Prognosemodel ROA-informatiesysteem onderwijs-arbeidsmarkt

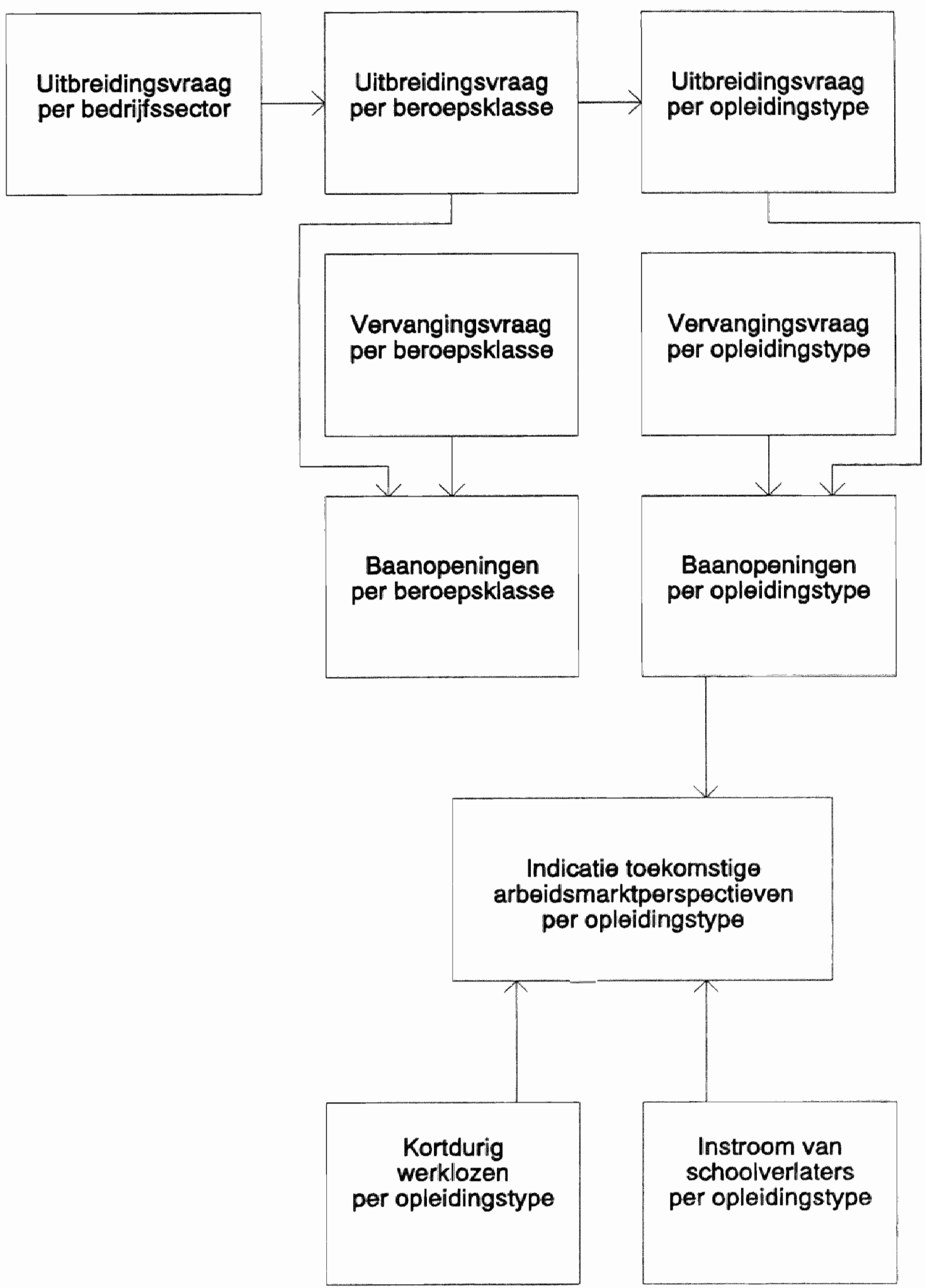


Het uitgangspunt voor de uitbreidingsvraagprognoses wordt gevorma door de middellangetermijn arbeidsmarktprognoses, verbijzonderd naar 12 bedrijfssectoren, die zijn opgesteld door het Centraal Planbureau (CPB). Met behulp van het 'ROA-beroepenmodel' wordt de sectorale werkgelegenheidsontwikkeling verdeeld naar beroepsklasse. In dit lgroei-/model wordt de beroepenstructuur binnen de bedrijfssectoren verklaard uit structurele effecten ('fixed coefficients'), groei in toegevoegde waarde, de effecten van arbeidsduurverkorting en eventuele trendeffecten (zie Borghans en Heijke, 1993a).

De uitbreidingsvraag per opleidingstype wordt vervolgens bepaald in het 'ROA-opleidingenmodel'. In dit model wordt de ontwikkeling van de opleidingenstructuur binnen de beroepen gemodelleerd aan de hand van structurele effecten en de geschatte tendensen in de vraag met betrekking tot het gevraagde opleidingsniveau. Daarnaast wordt in dit model rekening gehouden met substitutie-effecten als gevolg van veranderende vraag-aanbod-verhoudingen (zie verder Borghans en Heijke, 1993b).

De vervangingsvraag per beroepsklasse en opleidingstype wordt bepaald door de in het verleden waargenomen geslachts- en leeftijdsspecifieke netto verloopcoëfficiënten per beroepsklasse, respectievelijk opleidingstype te 'extrapoleren' naar de toekomst. Daarbij wordt gecorrigeerd voor het conjuncturele verloop, dat wil zeggen de uitstroom van werkenden naar werkloosheid. Daarnaast wordt rekening gehouden met de verwachte participatiegraadontwikkelingen. Tussen de vervangingsvraag per beroepsklasse en de vervangingsvraag per opleidingstype treedt een belangrijk verschilpunt op. De beroepsmobiliteit is namelijk wel van invloed op de vervangingsvraag per beroepsklasse, maar heeft daarentegen geen effect op de vervangingsvraag per opleidingstype (zie verder Willems en De Grip, 1992).

Het belangrijkste bestanddeel van de prognose van de instroom van schoolverlaters op de arbeidsmarkt bestaat uit de schoolverlatersprognoses van het Ministerie van Onderwijs en Wetenschappen (1993a). Daarnaast wordt gebruik gemaakt van uiteenlopende gegevens over de verwachte uitstroom uit het regulier deeltijdonderwijs en het niet-regulier onderwijs om te komen tot een raming van de instroom van schoolverlaters per ROA-opleidingstype (voor een verdere toelichting wordt verwezen naar Berendsen, Dekker, De Grip en Van de Loo, 1992).

\subsection{Arbeidsmarktprognoses voor technisch opgeleiden}

In deze paragraaf zal, zoals reeds eerder is opgemerkt, de haalbaarheid van het op een meer gedetailleerd niveau prognosticeren van de arbeidsmarkt voor technici worden onderzocht. Daarbij zal achtereenvolgens worden ingegaan op de verschillende stromen op de arbeidsmarkt, die de 'bouwstenen' vormen van de arbeidsmarktprognoses. Voor de uitbreidingsvraag en de vervangingsvraag geldt dat er in principe twee mogelijkheden zijn om de gedetailleerde arbeidsmarktprognoses voor technisch opgeleiden op te stellen. De eerste methode bestaat vit het herformuleren van de modellen op een lager aggregatieniveau. Bij de tweede methode worden daarentegen de bestaande prognoses voor de totale groep technisch opgeleiden, verbijzonderd naar opleidingsniveau, verdeeld naar een lager aggregatieniveau, door gebruik te 
maken van specifieke actuele gegevens en de (tussen)resultaten van de bestaande modellen. Een met deze laatste methode vergelijkbare methodiek is gebruikt door Berendsen, De Grip, Wieling en Willems (1992a, 1992b en 1993) voor het verbijzonderen van de bestaande landelijke prognoses naar provincie. Een voordeel van deze laatste aanpak is dat deze meer robuust is en dat bovendien de resultaten consistent zijn met de bestaande prognoses. Nadeel is echter dat de verschillen tussen de binnen de totale opleidingscategorie technisch opgeleiden onderscheiden vakrichtingen mogelijk enigszins worden onderschat. Beide mogelijke methodieken zullen in de rest van deze paragraaf per prognose-element nader worden uitgewerkt. Voor de prognose van de arbeidsmarktinstroom van schoolverlaters wordt echter slechts één variant besproken.

\section{Uitbreidingsvraag}

In paragraaf 3.2 is kort geschetst hoe de uitbreidingsvraagprognose naar beroepsklasse en opleidingstype tot stand komt. In figuur 3.2 is dit in iets verdergaande mate van detail nogmaals weergegeven. Vanuit de bedrijfssectorprognose van het CPB wordt in de eerste stap van het ROA-beroepenmodel een prognose opgesteld per beroepssegment. Deze beroepssegmenten zijn een aggregatie van de ROA-beroepsklassen (zie Van de Loo, Dekker en De Grip, 1992). Via trendextrapolatie komt vervolgens de uitbreidingsvraagprognose per beroepsklasse tot stand. De resultaten van de eerste stap van het beroepenmodel vormen de input voor fase 1 van het ROAopleidingenmodel, waarin onder meer rekening wordt gehouden met de trendmatige ontwikkelingen in het gevraagde opleidingsniveau. Door vervolgens in de tweede fase van het opleidingenmodel rekening te houden met de te verwachten vervangingsvraag en de verwachtingen omtrent het aanbod van nieuwkomers op de arbeidsmarkt wordt een indicatie verkregen van mogelijke 'additionele' substitutie-effecten. Deze ontstaan doordat een overschot aan aanbod op een deelmarkt naast een tekort op een naburige deelmarkt zal leiden tot aanpassingsstromen. Op deze manier wordt de uiteindelijke prognose van de uitbreidingsvraag verkregen (zie voor een verdere toelichting Borghans en Heijke, 1993b).

De eerste manier om de uitbreidingsvraagprognose per opleidingstype met name voor technisch opgeleiden nader te differentiëren, bestaat uit het aanpassen van het verklarend model en derhalve zowel de eerste als de tweede fase van het opleidingenmodel op een lager aggregatieniveau te schatten. Hierbij moet echter worden bedacht dat dit een grote wissel trekt op de kwaliteit van de data. Gezien de relatief grote mate van onbetrouwbaarheid van de kleine aantallen in de $E B B$, zal dat - vooral voor de onderscheiden technische opleidingen op academisch niveau - leiden tot of onbetrouwbare schattingsresultaten met derhalve zeer onzekere prognoses of zeer 'conservatieve' schattingen waarin weinig variatie in de prognoseresultaten voor de verschillende richtingen optreedt. Voor enkele richtingen in het MBO en het VBO zou een dergelijke aanpak, gelet op de grootte van de opleidingen"1 en de

11. In de rest van dit hoofdstuk wordt met 'opleidingstype' gedoeld op de ROA-opleidingstypen die momenteel in het informatiesysteem onderwijs-arbeidsmarkt worden onderscheiden. Met 'opleiding' wordt de verfijndere indeling bedoeid. 
wetenschappelijk onderwijs kan gebruik worden gemaakt van aanvullende gegevens van het Koninklijk Instituut van Ingenieurs (KIvl), zodat voor de onderscheiden WO-opleidingen wel specifieke prognoses kunnen worden opgesteld.

Figuur 3.3. Verdere detaillering van de uitbreidingsvraagprognose per opleiding

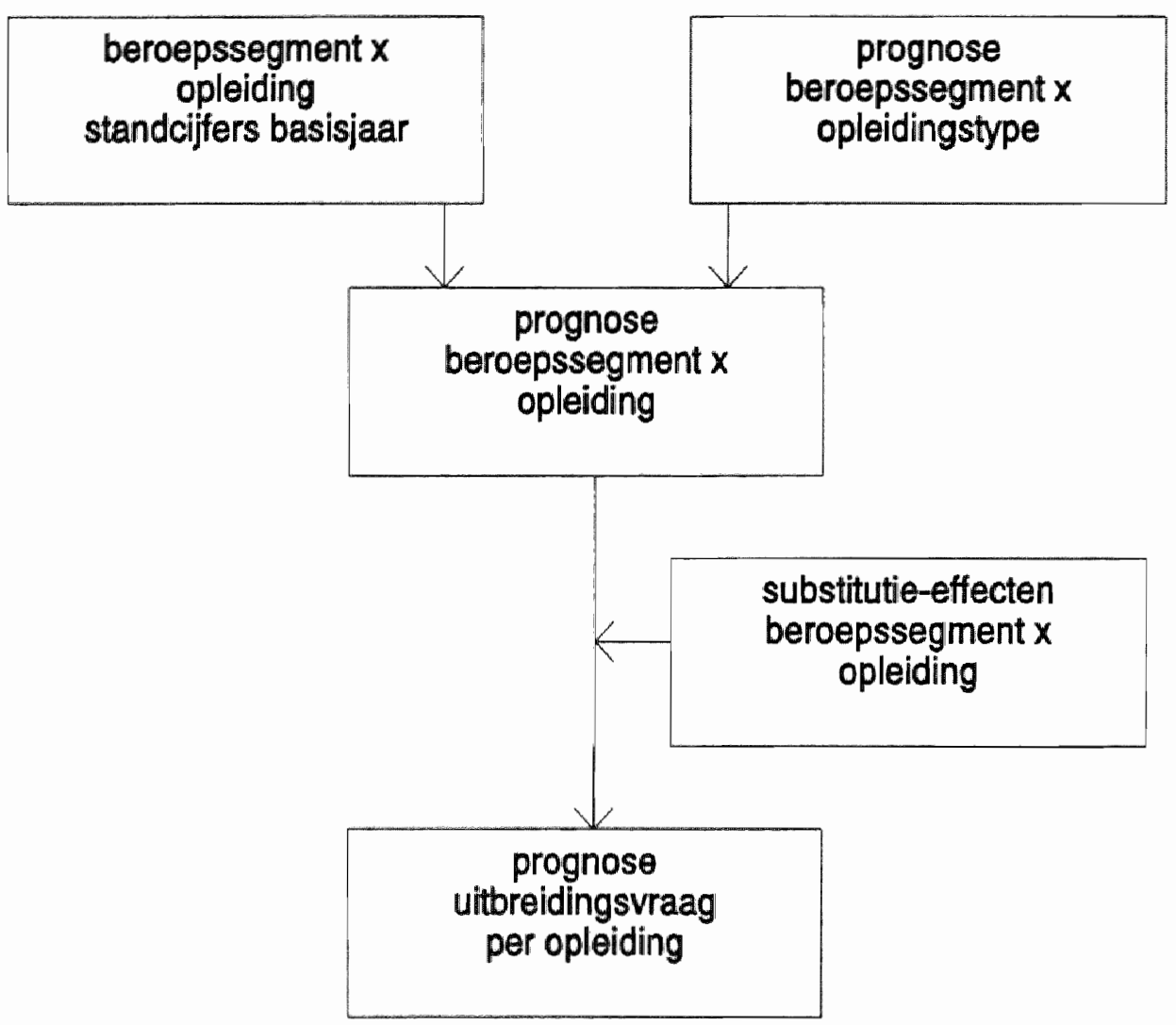

Vervangingsvraag

De volgende component van de prognosemethodiek die wordt besproken is de vervangingsvraag. Deze wordt, zoals gezegd, bepaald door de historische netto uitstroomcoëfficiënten per opleidingstype, leeftijdscategorie en geslacht te extrapoleren naar de prognoseperiode, daarbij rekening houdend met de historische conjuncturele schommelingen en eventuele toekomstige veranderingen in het participatiegedrag. Deze methodiek zou ook op het lagere aggregatieniveau van (technische) opleidingen kunnen worden uitgevoerd. Aangezien de methode grote eisen stelt aan de te gebruiken data, namelijk betrouwbare en voor twee momenten vergelijkbare gegevens over het aantal werkenden naar opleiding, geslacht en leeftijdscategorie, zal deze voor de kleine opleidingen niet goed bruikbaar zijn. Immers, relatief kleine (meet)fouten in de gegevens voor beide jaren kunnen leiden tot een relatief grote verstoring van de op basis van deze gegevens bepaalde verloopcoëfficiënten en daarmee tot een onbetrouwbare vervangingsvraagprognose. Daarnaast moet worden opgemerkt dat er momenteel nog geen data voor twee tijdstippen beschikbaar zijn, zodat het op deze wijze opstellen van de vervangingsvraagprognose 
überhaupt niet tot de mogelijkheden behoort.

Een andere manier om de vervangingsvraag op gedesaggregeerd niveau te bepalen, bestaat uit het relateren van de (gecorrigeerde) verloopcoëfficiënten voor de hoofdrichtingen (ROAopleidingstypen) aan de standcijfers van het aantal werkenden per opleiding, geslacht en leeftijd (zie figuur 3.4). Daar veel technische opleidingen binnen het desbetreffende opleidingstype verbijzonderd naar geslacht en leeftijdscategorie - naar verwachting eenzelfde verlooppatroon zullen kennen, en de verschillen in de vervangingsvraag tussen de richtingen derhalve vooral voort zullen vloeien uit de verschillen in de huidige geslachts- en leeftijdsopbouw van de desbetreffende opleiding, is deze methode een goed alternatief. Op deze manier zou voor alle onderscheiden technische richtingen op alle niveaus een vervangingsvraagprognose kunnen worden opgesteld. Wel moet daarbij worden bedacht dat voor kleine opleidingen de betrouwbaarheid van de cellen van de datamatrix opleiding $\times$ geslacht $\times$ leeftijd kleiner zal zijn, waardoor vanzelfsprekend de onzekerheidsmarge van de vervangingsvraagprognose wordt vergroot.

Figuur 3.4. Verdere detaillering van de vervangingsvraagprognose per opleiding

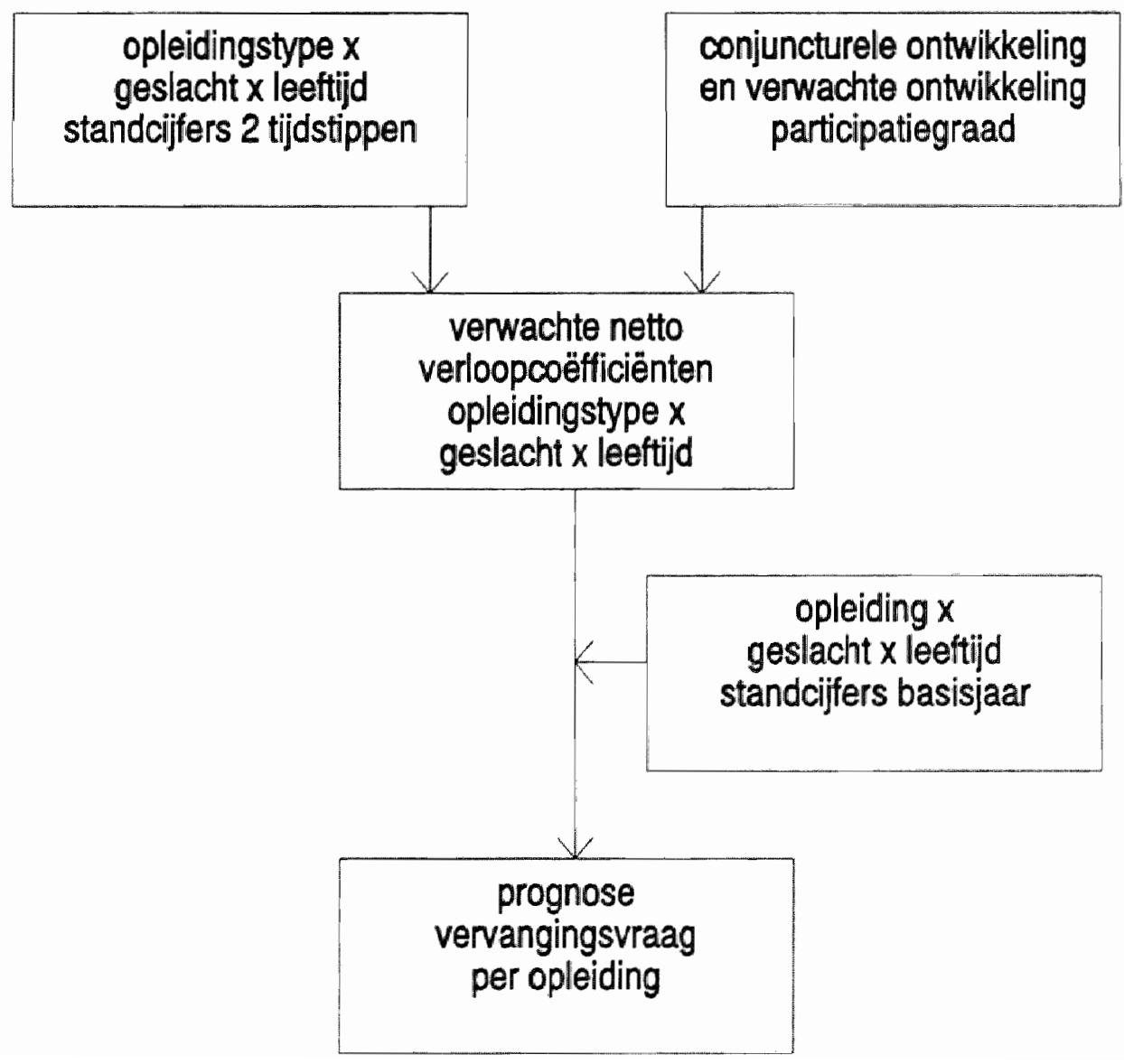


De prognosemethodiek voor de arbeidsmarktinstroom van schoolverlaters bestaat uit twee stappen. Het startpunt van de eerste stap wordt gevormd door de Referentieraming van het Ministerie van Onderwijs en Wetenschappen 11993a). Hierin is onder meer een prognose opgenomen van de schoolverlaters uit het initieel dagonderwijs, het kort MBO en het leerlingwezen. Bij deze prognose is een verbijzondering gemaakt naar opleidingsniveau en daarbinnen naar een beperkt aantal hoofdrichtingen (schoolsoorten). Ten behoeve van het huidige informatiesysteem onderwijs-arbeidsmarkt wordt deze prognose verbijzonderd naar de ROA-opleidingstypen met behulp van recente gegevens van onder meer de integrale Leerlingtelling $(L T)$ en werktabellen $\mathrm{HBO}^{13}$. Hierbij wordt derhalve verondersteld dat de verdeling van het aantal gediplomeerden naar ROA-opleidingstype binnen een in de Referentieraming onderscheiden hoofdrichting gelijk blijft. Daarnaast wordt voor het bepalen van de uitstroom van schoolverlaters uit het regulier voltijd onderwijs, verbijzonderd naar opleidingsrichting, gebruik gemaakt van de WO-Verdeelraming van het Ministerie van Onderwijs en Wetenschappen (1993b).

In de tweede stap van het prognosemodel wordt vervolgens rekening gehouden met de doorstroom naar en de uitstroom van het regulier deeltijdonderwijs - met uitzondering van het kort MBO - en het niet-regulier onderwijs, waaronder de diverse vormen van de beroepsgerichte volwasseneneducatie. Daarbij wordt als voorwaarde gesteld dat dit vervolgonderwijs niveauverhogend is. In deze tweede stap wordt gebruik gemaakt van een groot aantal databronnen (zıe verder Berendsen, Dekker, De Grip en Van de Loo, 1992).

Uit het bovenstaande blijkt dat het ROA voor de prognose van de arbeidsmarktinstroom van schoolverlaters niet zelf (econometrische) modellen opstelt, maar gebruik maakt van tal van beschikbare ramingen en aanvullende actuele gegevens. Dit betekent dat voor het verbijzonderen van deze prognoses naar de verschillende technische opleidingen slechts én methodiek mogelijk is en er derhalve geen keuze is tussen twee mogelijke opties, zoals dat bij de uitbreidingsvraag en de vervangingsvraag het geval is. De grote lijnen van het prognoseschema zijn weergegeven in figuur 3.5 .

In de eerste stap van dit prognosemodel worden de prognoses van de uitstroom van schoolverlaters volgens de Referentieraming direct verbijzonderd naar de gedetailleerde opleiding. Voor het WO kan daarvoor gebruik worden gemaakt van de WO-Verdeelraming. Voor het beroepsonderwijs zijn echter geen gedetailleerde prognoses beschikbaar. De veronderstelling dat de verdeling van het aantal gediplomeerden over de opleidingsrichtingen binnen de hoofdrichtingen van de Referentieraming constant blijft, is echter op dit gedetailleerde niveau van opleidingen minder plausibel. Aangezien echter voor een (beperkt) aantal jaren feitelijke gegevens over het aantal leerlingen in de diverse richtingen en verdeeld naar leerjaar bekend

13. Deze worden door het CBS voor de samenstelling van de Onderwijsmatrix gebruikt. 
zijn, zou op basis van deze tijdreeks een eenvoudig extrapolatiemodel ${ }^{14}$ kunnen worden opgesteld. Daarbij kan worden opgemerkt dat deze extrapolaties alleen betrekking hoeven te hebben op de leerlingen die momenteel nog niet de desbetreffende opleidingen volgen. Gezien de termijn van de prognoseperiode zal een dergelijke methodiek leiden tot een redelijk betrouwbare verdeling van de verwachte uitstroom naar opleiding. Bovendien kan worden opgemerkt dat ook de gegevens van RUBS en de HBO-Monitor op dit punt belangrijke inzichten kunnen verwerven.

In de tweede stap moet vervolgens rekening worden gehouden met de arbeidsmarktinstroom vanuit het deeltijd- en het niet-regulier onderwijs. Met name voor het hoger deeltijd-onderwijs en het leerlingwezen zijn hierover specifieke gegevens, verbijzonderd naar opleiding beschikbaar. Voor het leerlingwezen is binnen de Referentieraming een prognose van het totaal aantal gediplomeerden beschikbaar. Op basis van het bestand Opgave van Leerlingwezen (OVL) kan een onderverdeling naar richting worden gemaakt. Ook kan gebruik worden gemaakt van de Toekomstverkenning Leerlingwezen, die onlangs door het ROA is opgesteld (zie De Grip, Berendsen, Borghans en Dekker, 1993). Voor het merendeel van de deeltijd- en niet-reguliere opleidingen zijn echter slechts gegevens op een hoog aggregatieniveau voorhanden. Een noodzakelijke veronderstelling is derhalve dat de doorstroom naar en de uitstroom uit het deeltijd- en niet-regulier onderwijs relatief gezien voor de verschillende opleidingen binnen een ROA-opleidingstype gelijk blijft. De combinatie van de uitkomsten van deze tweede stap met de resultaten van stap 1 levert de prognose van de instroom van schoolverlaters op de arbeidsmarkt, verbijzonderd naar opleidingstype.

De hierboven beschreven methodiek is in principe toepasbaar voor alle onderscheiden technische opleidingen. Vooral voor het hoger onderwijs zijn in verregaande mate gedetailleerde gegevens beschikbaar. Met name voor de kleinere opleidingen op MBO- en VBO-niveau kan men zich echter afvragen in hoeverre de op deze manier verkregen prognoses betrouwbaar zullen zijn.

Het tweede deel van de instroom van nieuwkomers op de arbeidsmarkt bestaat, zoals aangegeven in paragraaf 3.2, uit het aanbod van kortdurig werklozen. In hoofdstuk 2 is reeds geschetst dat er momenteel niet of nauwelijks recente en gedetailleerde gegevens over de werkloosheid beschikbaar zijn. De enige mogelijkheid is dan ook om de (verouderde) gegevens van Arbeidsvoorziening te gebruiken om een herverdeling van de CBS-cijfers met betrekking tot de geregistreerde kortdurige werkloosheid naar opleidingsniveau te maken. Daarnaast kunnen de gegevens, evenals dat in de meest recente versie van het informatiesysteem is gedaan, worden geschaald naar het totaal aantal werklozen, waarvan het CPB uitgaat ${ }^{15}$.

14. Ook in de WO-Verdeelraming wordt gebruik gemaakt van een extrapolatiemodel.

15. Dit betreft de zogenaamde 'werkzoekenden zonder baan'. 
Figuur 3.5. Verdere detaillering van de prognose arbeidsmarktinstroom van schoolverlaters naar opleiding

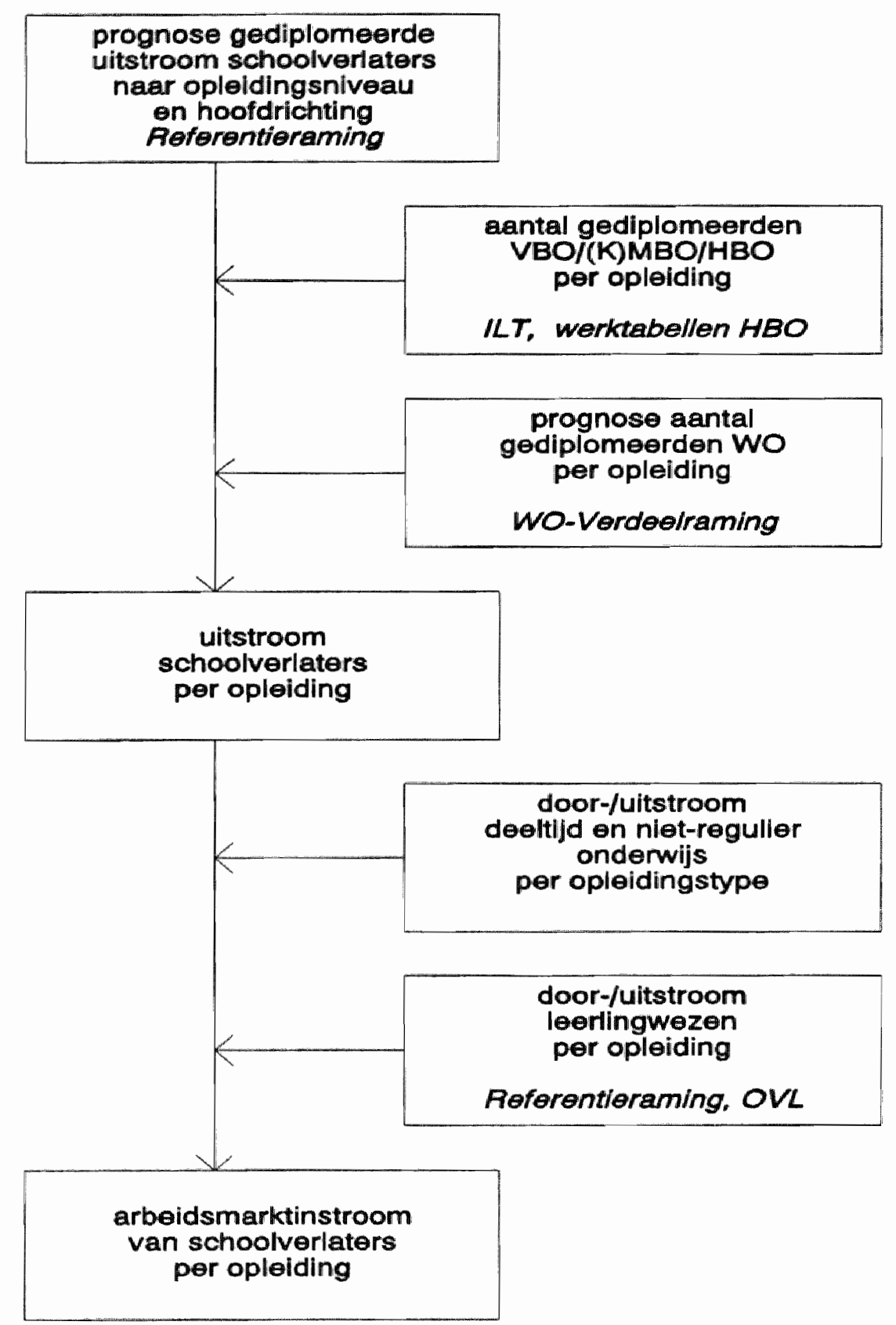

\subsection{Conclusies}

In dit hoofdstuk is de haalbaarheid van het opstellen van middellange-termijn arbeidsmarktprognoses voor een groot aantal richtingen van het technisch onderwijs onderzocht. Daarbij is per prognose-element (uitbreidingsvraag, vervangingsvraag en instroom van schoolverlaters) nagegaan of, en zo ja op welke manier, het mogelijk is om dergelijke prognoses op te stellen. In principe zijn er daarbij bij de uitbreidingsvraag en de vervangingsvraag twee varianten. De eerste 
variant bestaat uit het opnieuw specificeren van de bestaande modellen op een lager aggregatieniveau. In de tweede variant vindt binnen de bestaande modelstructuur een herverdeling naar richting plaats. Aangezien er momenteel nog geen voldoende lange tijdreeksgegevens op een laag aggregatieniveau beschikbaar zijn, is de eerste variant vooralsnog onmogelijk. Voor de tweede variant zijn echter geen tijdreeksen nodig, maar kan worden volstaan met de wel beschikbare standcijfers voor én bepaald jaar. In tabel 3.1 is per onderscheiden opleiding nagegaan of het mogelijk is prognoses op te stellen. In de laatste kolom van deze tabel staat weergegeven of het opstellen van een volledige arbeidsmarktprognose op basis van een confrontatie van vraag en aanbod mogelijk is.

Tabel 3.1. Mogelijkheid tot het opstellen van arbeidsmarktprognoses voor technisch opgeleiden naar opleidingsniveau en -richting, per prognose-element

\begin{tabular}{|c|c|c|c|c|}
\hline $\begin{array}{l}\text { Opleidingsniveau } \\
\text { en -richting }\end{array}$ & $\begin{array}{l}\text { uitbreidings- } \\
\text { vraag }\end{array}$ & $\begin{array}{c}\text { vervangings- } \\
\text { vraag }\end{array}$ & instroom & $\begin{array}{c}\text { confrontatie } \\
\text { vraag-aanbod }\end{array}$ \\
\hline \multicolumn{5}{|l|}{ Wetenschappelijk onderwijs } \\
\hline wis- en natuurkunde & ja & ja & ja & ja \\
\hline bouwkunde & ja & ja & ja & ja \\
\hline werktuigbouwkunde & ja & ja & ja & ja \\
\hline elektrotechniek & ja & ja & ja & ja \\
\hline \multicolumn{5}{|l|}{ Hoger beroepsonderwijs } \\
\hline technisch laboratorium & ja & ja & ja & ja \\
\hline bouwkunde & ja & ja & ja & ja \\
\hline werktuigbouwkunde & ja & ja & ja & ja \\
\hline elektrotechniek & ja & ja & ja & já \\
\hline \multicolumn{5}{|l|}{ Middelbaar beroepsonderwijs } \\
\hline technisch laboratorium & ja & ja & ja & ja \\
\hline bouwkunde & ja & ja & ja & ja \\
\hline weg-en waterbouwkunde & $?$ & ja & ja & $?$ \\
\hline metaalkunde & ja & ja & ja & ja \\
\hline fijnmechanische techniek & $?$ & ja & ja & $?$ \\
\hline werktuigbouwkunde & ja & ja & ja & ja \\
\hline motorvoertuigentechniek & ja & ja & ja & ja \\
\hline elektrotechniek & ja & ja & ja & ja \\
\hline procestechniek & $?$ & ja & ja & $?$ \\
\hline \multicolumn{5}{|l|}{ Voorbereidend beroepsonderwijs } \\
\hline bouwtechniek & ja & ja & ja & ja \\
\hline installatietechniek & nee & $?$ & ja & nee \\
\hline metaalkunde & ja & ja & ja & ja \\
\hline werktuigbouwkunde & nee & $?$ & $?$ & nee \\
\hline motorvoertuigentechniek & ja & ja & ja & ja \\
\hline elektratechniek & ja & ja & ja & la \\
\hline grafische techniek & nee & $?$ & ja & nee \\
\hline consumptieve techniek & ja & ja & ja & ja \\
\hline
\end{tabular}

Geconcludeerd kan worden dat het voor de onderscheiden technische opleidingen op WOniveau mogelijk is om binnen het kader van het ROA-informatiesysteem onderwijs-arbeidsmarkt arbeidsmarktprognoses op te stellen. Daartoe wordt dan niet alleen gebruik gemaakt van de 
beschikbare EBB-gegevens, maar deze zullen worden 'gekoppeld' aan gegevens, die zijn ontleend aan een enquête onder de leden van het Klvl. Met name voor de uitbreidingsvraag bieden de Klvl-gegevens mogelijkheden om tot een verdere verbijzondering van de prognoses te komen. Voor de vervangingsvraagprognose zal waarschijnlijk alleen gebruik worden gemaakt van de EBB-gegevens. Dit betekent dat met name voor de twee kleinere WO-opleidingen werktuigbouwkunde en elektrotechniek de vervangingsvraagprognose wat meer onzeker zal zijn. Vooralsnog wordt er echter vanuit gegaan dat het opstellen van de prognose van de vervangingsvraag op het gedetailleerde niveau van opleidingen mogelijk is, mede doordat gebruik kan worden gemaakt van verlooppatronen bij 'verwante' studierichtingen. Tenslotte is het sowieso goed mogelijk om een inschatting te maken van de toekomstige instroom van schoolverlaters op de arbeidsmarkt.

Voor de onderscheiden HBO-opleidingen wordt de mogelijkheid tot het opstellen van prognoses op basis van de beschikbare EBB-gegevens gunstig ingeschat. Het opstellen van de prognoses van de vervangingsvraag en de arbeidsmarktinstroom van schoolverlaters blijkt eveneens mogelijk te zijn, zodat ook een vraag-aanbod confrontatie voor de onderscheiden richtingen te realiseren zal zijn.

Op MBO-niveau is er een drietal kleine opleidingen waarvoor het opstellen van arbeidsmarktprognoses waarschijnlijk niet mogelijk is. Dit betreft de richtingen weg- en waterbouwkunde, fijnmechanische techniek en procestechniek. Vooral ten aanzien van de uitbreidingsvraagprognose zullen bij deze richtingen mogelijk onaanvaardbare onnauwkeurigheden ontstaan. Ook bij de beide andere prognose-elementen zal de onzekerheidsmarge echter waarschijnlijk relatief groot zijn.

Een soortgelijk beeld bestaat er met betrekking tot de opleidingen in het VBO. Ook hier zijn er drie kleine richtingen, te weten installatietechniek, werktuigbouwkunde en grafische techniek, waarvoor het waarschijnlijk onmogelijk zal zijn een (volledige) arbeidsmarktprognose op te stellen. Het spreekt voor zich dat ook in dit geval vooral het opstellen van de uitbreidingsvraagprognose problemen met zich meebrengt.

Op basis van tabel 3.1 kan worden geconcludeerd dat de uitbreidingsvraagprognose in het algemeen het belangrijkste kneipunt is bij het opstellen van de arbeidsmarktprognoses voor technisch opgeleiden. Ofschoon het niet direct uit de tabel blijkt, kunnen ook bij de gedetailleerde raming van de arbeidsmarktinstroom van schoolverlaters bij met name het MBO en het VBO echter belangrijke onzekerheden ontstaan. Voor het tot stand brengen van deze prognose zijn namelijk enkele veronderstellingen, hoofdzakelijk met betrekking tot de doorstroom naar het deeltijd en het niet-regulier onderwijs, noodzakelijk (zie ook Berendsen, Dekker, De Grip en Van de Loo, 1992). Een deel van deze veronderstellingen zal echter op een meer gedesaggregeerd niveau minder plausibel zijn. Bij de vervangingsvraag zal een verdergaande mate van detaillering goed te realiseren zijn.

De slotconclusie van dit hoofdstuk kan dan als volgt worden samengevat. Voor de WO- 
opleidingen is een verdere detaillering van de prognoses binnen de context van het ROAinformatiesysteem onderwijs-arbeidsmarkt zeer waarschijnlijk mogelijk, mede doordat naast de $E B B$-gegevens aanvullende data van het KIvl kunnen worden gebruikt. Op HBO-niveau kan eveneens een differentiatie naar richting worden aangebracht door middel van het 'verdelen' van de huidige prognose voor het ROA-opleidingstype 'HBO technisch' naar de drie onderliggende richtingen. Met uitzondering van enkele kleine richtingen kan voor de opleidingen op MBO- en VBO-niveau een volledige arbeidsmarktprognose worden gerealiseerd. Daarbij moet vooralsnog worden gekozen voor een nadere verbijzondering van de bestaande prognoses, aangezien momenteel nog geen tijdreeksgegevens op het in dit rapport gehanteerde lage aggregatieniveau van opleidingen beschikbaar zijn. Op termijn zal het echter waarschijnlijk mogelijk zijn om de modellen te specificeren op het lagere aggregatieniveau. 


\section{MOGELIJKE AANVULLENDE GEGEVENS}

\subsection{Inleiding}

Tot zover is in dit rapport slechts ingegaan op arbeidsmarktgegevens van technisch opgeleiden die van direct belang zijn voor het opstellen van middellange-termijn prognoses. Daarvoor zijn tevens enkele actuele arbeidsmarktgegevens besproken. Het is echter van belang om de arbeidsmarktpositie van bepaalde opleidingen in een breed kader te bezien. Dit betekent dat niet alleen op de actuele en de toekomstige marktpositie moet worden ingegaan, maar dat eveneens de risicopositie moet worden belicht. Daarnaast bieden gegevens over de arbeidsmarktpositie van schoolverlaters en recent afgestudeerden een inzicht in de directe aansluiting tussen het technisch onderwijs en de arbeidsmarkt.

In dit hoofdstuk worden enkele voorstellen gedaan voor het verzamelen van informatie met betrekking tot de arbeidsmarktpositie van technisch opgeleiden, additioneel aan de in hoofdstuk 2 beschreven gegevens. Het gaat daarbij zowel om actuele gegevens als om enkele risicoindicatoren. Eerst wordt in paragraaf 4.2 ingegaan op gegevens die betrekking hebben op de technisch opgeleide beroepsbevolking. In paragraaf 4.3 komen vervolgens enkele aanvullende gegevens over de schoolverlaters en recent afgestudeerden met een technische opleidingsachtergrond aan de orde.

\subsection{Gegevens met betrekking tot de beroepsbevolking}

Naast de in hoofdstuk 2 gepresenteerde gegevens over het aantal werkende technisch opgeleiden, verbijzonderd naar respectievelijk geslacht, bedrijfssector en beroepsklasse, zouden nog enkele andere EBB-gegevens kunnen worden verzameld, die een beter inzicht geven in de arbeidsmarktpositie van technisch opgeleiden. Zo is het wenselijk om de gegevens van het aantal werkende technisch opgeleiden te verbijzonderen naar de wekelijkse arbeidsduur. Enerzijds kan dit een aanvullend inzicht geven in de schaarsteverhoudingen op de arbeidsmarkt. Een groot percentage deeltijdwerkers kan er op wijzen dat er ruimte op de arbeidsmarkt is. De totale werkgelegenheids'koek' moet dan onder meer gegadigden worden verdeeld. Anderzijds geeft dit mogelijk ook een indicatie van de mogelijkheden voor technisch opgeleiden om in deeltijd te werken. Een grote mate van flexibiliteit in de wekelijkse arbeidstijd wordt immers door de aanbieders van arbeid in toenemende mate gezien als een aantrekkelijk kenmerk van de arbeidsmarktpositie.

Een tweede belangrijke aanvullende indicator betreft de conjunctuurgevoeligheid van de werkgelegenheid. Hiermee wordt aangegeven in hoeverre de werkgelegenheid fluctueert met de economische situatie. Dit houdt in dat de conjunctuurgevoeligheid een maat vormt voor de werkzekerheid van de arbeidskrachten met een bepaalde opleidingsachtergrond ${ }^{16}$. Een verbij-

\footnotetext{
16. Momenteel is de conjunctuurgevoeligheid alleen op het niveau van beroepsklassen in het informatiesysteem opgenomen.
} 
zondering van de conjunctuurgevoeligheid naar opleidingen is mogelijk (zie bijvoorbeeld De Grip, Van der Velden en Wieling, 1993b).

Tenslotte kan met de EBB-gegevens een indicatie worden verkregen van de uitwijkmogelijkheden op de arbeidsmarkt. Met behulp van de Gini-Hirschman spreidingsindex kan worden bepaald in hoeverre arbeidskrachten slechts in een beperkt aantal bedrijfssectoren of beroepsgroepen zijn geconcentreerd, of dat zij in vele verschillende arbeidsmarktsegmenten werkzaam zijn (zie bijvoorbeeld De Grip, Van der Velden en Wieling, 1993b). Dit geeft een beeld van hun flexibiliteit op de arbeidsmarkt. Als de werkgelegenheid voor een bepaalde groep technisch opgeleiden sterk in eén segment van de arbeidsmarkt is geconcentreerd, betekent dit dat deze opleidingscategorie in sterke mate afhankelijk is van de arbeidsmarktsituatie in dat segment. Indien echter werkenden met een bepaalde opleidingsachtergrond in veel verschillende segmenten zijn vertegenwoordigd, hebben zij meer mogelijkheden om bij een achterblijvende vraag in het ene segment uit te wijken naar andere arbeidsmarktsegmenten waar de perspectieven wellicht gunstiger zijn.

Momenteel zijn de uitwijkmogelijkheden, verbijzonderd naar de onderscheiden ROAopleidingstypen in het informatiesysteem onderwijs-arbeidsmarkt opgenomen. Met vitzondering van de laboratoriumopleidingen worden deze uitwijkmogelijkheden voor technisch opgeleiden in het algemeen als relatief groot getypeerd. Voor de afzonderlijke richtingen zijn de uitwijkmogelijkheden echter wellicht veel geringer (zie bijvoorbeeld Wieling, De Grip en Van der Velden, 1992). Door per opleidingsniveau alle technische opleidingen als eén cluster te zien, wordt in feite verondersteld dat tussen de verschillende onderliggende opleidingsrichtingen een grote mate van substitutie mogelijk is. Gezien het feit dat tussen de diverse technische opleidingen belangrijke verschillen bestaan, lijkt dit minder waarschijnlijk. Wel kan in dit verband worden opgemerkt dat een groot aantal werkenden met een technische opleidingsachtergrond niet werkzaam is in het beroep waarvoor men oorspronkelijk is opgeleid (zie hoofdstuk 2 ).

\subsection{Gegevens met betrekking tot schoolverlaters en recent afgestudeerden}

Een belangrijk instrument om de arbeidsmarktpositie van technisch opgeleiden nader te belichten, bestaat uit het 'monitoren' van de positie die schoolverlaters en recent afgestudeerden op de arbeidsmarkt innemen. Hiermee wordt een beter beeld verkregen van de directe aansluiting tussen de opleiding en de arbeidsmarkt. Bovendien is de eerste bestemming voor veel nieuwkomers op de arbeidsmarkt in belangrijke mate bepalend voor hun verdere loopbaan. Daarmee geven de schoolverlatersdata ook een beeld van de te verwachten toekomstige ontwikkelingen.

Zoals in hoofdstuk 2 bij de bespreking van de data-infrastructuur reeds is opgemerkt, beschikt het ROA over een tweetal gegevensbestanden die betrekking hebben op de arbeidsmarktpositie van schoolverlaters van het AVO, het VBO, het MBO en het HBO. Onlangs is door het ROA een verkennend onderzoek afgerond om de gegevens van beide schoolverlatersonderzoeken in het informatiesysteem onderwijs-arbeidsmarkt in te passen (zie De Grip. Van der Velden en Wieling. 
1993a). In dat onderzoek wordt geconcludeerd dat het inpassen van deze gegevens zowel conceptuele als praktische voordelen heeft. In de eerste plaats kan op een groter aantal items dan met de $E B B$ het geval is informatie worden verschaft. Voorbeelden hiervan zijn de beloningsverhoudingen tussen de opleidingen en de mate waarin werkenden in hun eigen vakrichting terechtkomen. Bovendien is het mogelijk gebleken om op een veel relevanter niveau van opleidingen dan in het huidige informatiesysteem de aansluitingsproblematiek tussen onderwijs en arbeidsmarkt in beeld te brengen. Daarnaast hebben de gegevens het voordeel dat zij, zoals hierboven reeds is aangegeven, betrekking hebben op de directe aansluiting tussen de opleiding en de arbeidsmarkt.

In deze paragraaf worden enkele gegevens bijeengebracht met betrekking tot de arbeidsmarktpositie van schoolverlaters en recent afgestudeerden van het technisch onderwijs. De gegevens zijn gebaseerd op de meeste recente RUBS-enquête en HBO-Monitor. Beide enquêtes hebben betrekking op de schoolverlaters van het schooljaar 1990/1991. Wel moet worden beseft dat de RUBS-enquete (voor VBO en MBO) heeft plaatsgevonden in het voorjaar van 1992, terwijl de enquete van de HBO-Monitor in de winter van 1992/1993 is afgenomen. De RUBS-gegevens zijn grotendeels eerder gepresenteerd in het rapport De inpassing van schoo/verlatersinformatie in het ROA-informatiesysteem anderwijs-arbeidsmarkt (De Grip, Van der Velden en Wieling, 1993a)", terwijl een aantal gegevens van de HBO-Monitor ook zijn weergegeven in De arbeidsmarkt naar opleiding en beroep tot 1998 (ROA, 1993a). Helaas kunnen in deze paragraaf geen gegevens worden gepresenteerd over de recent afgestudeerden van de universiteiten, aangezien voor het WO een dergelijk grootschalig onderzoek niet wordt uitgevoerd.

De gegevens kunnen in twee categorieën worden verdeeld, namelijk informatie met betrekking tot de actuele marktpositie en informatie betreffende de risicopositie van schoolverlaters. De actuele marktpositie zal achtereenvolgens worden belicht aan de hand van de werkloosheid, het aandeel van de werkenden dat in hun kwalificaties wordt onderbenut, de verdiende inkomens en de mate van deeltijdarbeid. Bij de risicopositie komen de conjunctuurgevoeligheid van de werkgelegenheid en de uitwijkmogelijkheden op de arbeidsmarkt aan de orde. Tevens wordt nagegaan in welke mate technisch opgeleiden schoolverlaters niet in technische beroepen werkzaam zijn.

\section{Werkloosheid}

Eén van de belangrijkste indicatoren die een beeld geven van de actuele arbeidsmarktsituatie voor nieuwkomers op de arbeidsmarkt betreft het werkloosheidspercentage onder deze groep. Een bij het aanbod achterblijvende vraag laat zich in belangrijke mate gelden door een beperking van de opnamecapaciteit van de markt, waardoor er vooral bij schoolverlaters en recent afgestudeerden sprake is van een hogere werkloosheid. Tabel 4.1 presenteert de naar opleidingsniveau en -richting verbijzonderde werkloosheidsgegevens voor de nieuwkomers op de

17. De in dat rapport gepresenteerde HBO-Monitor-data hebben betrekking op de afgestudeerden van het jaar $1989 / 1990$. 
arbeidsmarkt. Opgemerkt moet worden dat voor een drietal richtingen, te weten MBO weg- en waterbouwkunde, MBO procestechniek en VBO werktuigbouwkunde geen gegevens kunnen worden gepresenteerd, omdat het aantal (in de enquete opgenomen) schoolverlaters in deze richtingen te klein is.

Het blijkt dat er voor de HBO-afgestudeerden sprake is van een vrij hoge werkloosheid. De werkloosheid onder technisch opgeleide schoolverlaters van het MBO en het VBO is lager, al moet bij deze resultaten worden opgemerkt dat zoals gezegd het enquêtemoment voor HBO later was dan voor MBO en VBO. Het verschil kan dus (voor een deel) worden toegeschreven aan de toegenomen economische recessie.

Tabel 4.1. Werkloosheid onder schoolverlaters en recent afgestudeerden naar opleidingsniveau en -richting 1992

Opleidingsniveau en -richting

Hoger beroepsonderwijs

Technisch laboratorium

Technisch

bouwkunde

werktuigbouwkunde

elektrotechniek

Middelbaar beroepsonderwijs

$\begin{array}{ll}\text { Technisch laboratorium } & 6\end{array}$

$\begin{array}{ll}\text { Technisch } & 4\end{array}$

2

weg- en waterbouwkunde

metaalkunde techniek

fijnmechanische techniek $\quad 3$

werktuigbouwkunde 13

\begin{tabular}{ll} 
matorvoertuigentechniek & 2 \\
\hline
\end{tabular}

procestechniek

Voorbereidend beroepsonderwijs

Technisch

bouwtechniek

installatietechniek

metaalkunde

werktuigbouwkunde

motorvoertuigentechniek

elektrotechniek

grafische techniek

consumptieve techniek

geen informatie i.v.m. te weinig waarnemingen 
Binnen het HBO is vooral voor de afgestudeerden in de elektrotechniek de werkloosheid relatief hoog. Ten aanzien van het $\mathrm{MBO}$ is de werkloosheid met name onder de schoolverlaters van de opleiding de fijnmechanische techniek hoger. Ook de schoolverlaters in de richting technisch laboratorium zijn in verhouding tot de andere middelbaar technisch opgeleiden vaak werkloos. De richtingen bouwkunde, metaalkunde en motorvoertuigentechniek worden daarentegen gekenmerkt door een relatief lage werkloosheid onder schoolverlaters. Op VBO-niveau blijken vooral de schoolverlaters met als specialisaties elektrotechniek en grafische techniek relatief vaak werkloos te zijn.

Tabel 4.2. Duur van de intredewerkloosheid onder schoolverlaters en recent afgestudeerden naar opleidingsniveau en -richting 1992

Opleidingsniveau en -richting

$\begin{array}{cccc}\text { niet werkloos } & 1-3 & 4-6 & \text { meer dan } 6 \\ \text { geweest } & \text { maanden } & \text { maanden } & \text { maanden } \\ \% & \% & \% & \%\end{array}$

Hoger beroepsonderwijs

Technisch laboratorium

Technisch

bouwkunde

werktuigbouwkunde

elektrotechniek

$\begin{array}{rrrr}64 & 25 & 9 & 2 \\ 55 & 33 & 8 & 4 \\ 74 & 23 & 2 & 1 \\ 48 & 41 & 8 & 2 \\ 49 & 35 & 10 & 7\end{array}$

Middelbaar beroepsonderwijs

Technisch laboratorium

$\begin{array}{rrrr}65 & 27 & 8 & 2 \\ 75 & 17 & 5 & 3 \\ 83 & 14 & 3 & 1 \\ 72 & 21 & 8 & 0 \\ 63 & 21 & 9 & 8 \\ 80 & 14 & 4 & 2 \\ 87 & 8 & 2 & 2 \\ 73 & 20 & 5 & 2 \\ . & . & . & .\end{array}$

Voorbereidend beroepsonderwijs

Technisch

bouwtechniek

installatietechniek

metaalkunde

werktuigbouwkunde

motorvoertuigentechniek

elektrotechniek

grafische techniek

consumptieve techniek

$\begin{array}{rrrr}86 & 10 & 2 & 2 \\ 91 & 7 & 2 & 1 \\ 87 & 13 & 0 & 0 \\ 90 & 9 & 1 & 0 \\ 86 & 10 & 1 & 2 \\ 85 & 11 & 1 & 2 \\ 67 & 17 & 5 & 10 \\ 84 & 12 & 3 & 1\end{array}$

. = geen informatie i.v.m. te weinig waarnemingen

Bron: RUBS/HBO-Monitor/ROA

Niet alleen het werkloosheidspercentage, maar ook de tijd die nieuwkomers gemiddeld nodig hebben om een baan te vinden geeft een belangrijk zicht op hun actuele marktpositie. Deze 
intredewerkloosheid wordt daarbij niet beperkt tot de zoektijd van de eerste baan, maar betreft de totale zoektijd gedurende de gehele intredeperiode ${ }^{i 8}$. Dit heeft als voordeel dat rekening wordt gehouden met eventuele meerdere werkloosheidsperioden, die zijn onderbroken door korte baanduren.

In tabel 4.2 wordt een overzicht gegeven van de intredewerkloosheid. Voor een deel schetst deze tabel een soortgelijk beeld als bij de gepresenteerde werkloosheidspercentages. Toch geven deze gegevens enkele aanvullende informatie. Zo blijkt bijvoorbeeld dat naast de afgestudeerden in de richting HBO elektrotechniek ook de HBO-ers werktuigbouwkunde wat moeilijker een baan hebben gevonden dan andere technisch opgeleide $\mathrm{HBO}$-ers.

In aanvulling op de werkloosheidspercentages voor $\mathrm{MBO}$ - en VBO-schoolverlaters kan worden geconstateerd dat ook voor de MBO-opgeleiden in de elektrotechniek en de metaalkunde de intrede op de arbeidsmarkt minder soepel verloopt. Verder bevestigt de tabel de absorptieproblemen voor de $\mathrm{MBO}$-schoolverlaters in de richting fijnmechanische techniek. Op VBO-niveau blijkt dat de intredewerkloosheid vooral voor de richting grafische techniek relatief hoog is. Bij de richting elektrotechniek heeft, ondanks de relatief hoge werkloosheid, een groot deel van de werkenden binnen drie maanden een baan gevonden.

\section{Onderbenutting}

Absorptieproblemen op de arbeidsmarkt kunnen niet alleen in kwantitatieve zin, door middel van een hogere werkloosheid, maar ook in kwalitatieve zin tot uiting komen. Schoolverlaters en afgestudeerden kunnen een baan beneden hun niveau accepteren om zo in feite een dreigende werkloosheid 'af te kopen'. Tabel 4.3 laat zien in welke mate de werkende schoolverlaters in hun kwalificaties worden onderbenut, zoals bepaald op basis van de door de schoolverlaters aangegeven opleidingsvereisten voor de functie die zij uitoefenen.

Voor de recent afgestudeerde technici van het HBO is het percentage onderbenutting het laagst bij de richting technisch laboratorium. Tussen de overige HBO-opleidingen in de technische richting bestaat er wat dit betreft weinig verschil. De onderbenutting bij MBO-schoolverlaters blijkt duidelijk hoger te zijn dan bij de afgestudeerden van het HBO. Meest opvallend is daarbij de richting metaalkunde, waar maar liefst $57 \%$ van de werkende schoolverlaters in hun kwalificaties wordt onderbenut. Ook bij de richting elektrotechniek is de onderbenutting aan de hoge kant. Daarbij kan worden opgemerkt dat tot deze beide richtingen een groot aantal schoolverlaters van het kort MBO worden gerekend. Voor de richting fijnmechanische techniek geldt daarentegen dat de mate van onderbenutting relatief gering is. Dit betekent dat er weliswaar sprake is van een verhoudingsgewijs hoge werkloosheid onder de schoolverlaters van deze richting, maar als zij een baan hebben gevonden sluit die qua niveau vaak wel goed aan bij hun kwalificaties.

18. Dit is de periode van schoolverlaten/afstuderen tot het enquêtemoment. Daarbij moet worden opgemerkt dat deze periode, zoals reeds is opgemerkt, bij de HBO-Monitor langer is, door het verschil in het tijdstip van enquêteren. 
De gemiddelde onderbenutting bij de technisch opgeleide VBO-schoolverlaters is iets geringer dan bij de MBO-ers. Bij de richting grafische techniek blijkt echter dat de slechtere arbeidsmarktsituatie niet alleen tot uitdrukking komt in een hogere werkloosheid, maar dat voor degenen die wel werk hebben gevonden dit relatief vaak een baan onder hun niveau betreft. De schoolverlaters met als specialisatie installatietechniek hebben daarentegen in grote mate een baan op hun niveau gevonden.

Tabel 4.3. Percentage werkende schoolverlaters en recent afgestudeerden dat wordt onderbenut naar opleidingsniveau en -richting 1992

Opleidingsniveau en -richting $\quad \%$

Hoger beroepsonderwijs

Technisch laboratorium

Technisch

bouwkunde 14

werktuigbouwkunde 13

elektrotechniek 14

Middelbaar beroepsonderwijs

Technisch laboratorium $\quad 21$

$\begin{array}{ll}\text { Technisch } & 27\end{array}$

bouwkunde 23

weg" en waterbouwkunde

$\begin{array}{ll}\text { metaalkunde } & 57 \\ \text { fijmmechanische techniek } & 18\end{array}$

$\begin{array}{ll}\text { werktuigbouwkunde } & 18\end{array}$

motorvoertuigentechniek 15

elektrotechniek 24

procestechniek

Voorbereidend beroepsonderwijs

Technisch 16

bouwtechniek 13

installatietechniek 13

metaalkunde $\quad 13$

werktuigbouwkunde

elektrotechniek 19

grafische techniek 22

consumptieve techniek 17

. = geen informatie i.v.m. te weinig waarnemingen

Bron: RUBS/HBO-Monitor/ROA

Inkomen

Een uiterst interessant arbeidsmarktaspect betreft vanzelfsprekend het inkomen. In tabel 4.4 is het gemiddeld uurloon voor de werkende schoolverlaters en recent afgestudeerden gepresenteerd. Daarbij moet worden opgemerkt dat dit voor HBO-ers de bruto uurlonen betreft, 
terwijl voor de MBO-ers en VBO-ers de netto uurlonen zijn gemeten.

Binnen de technische HBO-opleidingen verdienen de afgestudeerden in de richting elektrotechniek het meest. Dit is opmerkelijk daar voor deze categorie de werkloosheid juist verhoudingsgewijs hoog is. De afgestudeerden in de richting technisch laboratorium hebben naar verhouding het laagste salaris. Het verschil met de elektrotechnici bedraagt gemiddeld genomen ongeveer 175 gulden bruto per maand, bij een volledige werkweek.

Tabel 4.4. Gemiddeld uurloon ${ }^{\circ}$ werkende schoolverlaters en recent afgestudeerden naar opleidingsniveau en -richting 1992

Opleidingsniveau en -richting

guldens

Hoger beroepsonderwijs

Technisch laboratorium

Technisch

19,82

bouwkunde

18,97

werktuigbouwkunde

19,58

elektrotechniek

19,83

Middelbaar beroepsonderwijs

Technisch laboratorium

Technisch

bouwkunde

9,56

weg-en waterbouwkunde

metaalkunde

8,26

fijnmechanische techniek

9,98

werktuigbouwkunde

10,29

motorvoertuigentechniek

9,86

elektrotechniek

9,59

procestechniek

Voorbereidend beroepsonderwijs

Technisch

6,00

bouwtechniek

installatietechniek

metaalkunde

5,90

werktuigbouwkunde

motorvoertuigentechniek

elektrotechniek

7,35

grafische techniek

6,47

. = geen informatie i.v.m. te weinig waarnemingen

- voor HBO-afgestudeerden bruto uurloon; voor MBO- en VBO-schoolverlaters netto uurloon

Bron: RUBS/HBO-Monitor/ROA

Op MBO-niveau hebben de richtingen werktuigbouwkunde en, gezien het beeld op HBO-niveau opvallend genoeg, technisch laboratorium het hoogste inkomen. Schoolverlaters in de richting metaalkunde verdienen daarentegen in vergelijking met de andere schoolverlaters van het MBO 
technisch een laag inkomen. Dit hangt ongetwijfeld samen met het feit dat relatief veel schoolverlaters een functie beneden MBO-niveau bekleden. Bij de VBO-opleidingen is het opmerkelijk dat de schoolverlaters van de richting grafische techniek een verhoudingsgewijs hoog inkomen verdienen. Hiervoor is immers gebleken dat de werkloosheid onder deze schoolverlaters relatief groot is, terwijl bovendien naar verhouding veel schoolverlaters een baan onder VBO-niveau hebben moeten accepteren. Degenen met als specialisatie motorvoertuigentechniek blijken gemiddeld gezien het laagste inkomen te hebben. Bij deze opleiding is de werkloosheid en de mate van onderbenutting echter relatief laag.

\section{Deeltijdarbeid}

Tabel 4.5. Percentage deeltijdwerkers bij werkende schoolverlaters en recent afgestudeerden naar opleidingsniveau en -richting 1992

Opleidingsniveau en -richting

Hoger beroepsonderwijs

Technisch laboratorium

1

Technisch

bouwkunde

werktuigbouwkunde

elektrotechniek

Midde/baar beroepsonderwijs

Technisch laboratorium

Technisch 21

bouwkunde

weg- en waterbouwkunde

metaalkunde

fijnmechanische techniek

werktuigbouwkunde

motorvoertuigentechniek

elektrotechniek

procestechniek

Voorbereidend beroepsonderwijs

Technisch

bouwtechniek

installatietechniek

metaalkunde

werktuigbouwkunde

motorvoertuigentechniek

elektrotechniek

grafische techniek

consumptieve techniek

71

77

68

63

77

70

35

79

. - geen informatie i.v.m. te weinig waarnemingen

Bron: RUBS/HBO-Monitar/ROA

Tabel 4.5 geeft een beeld van het aandeel van de werkende schoolverlaters dat een deeltijdbaan van 32 uur of minder per week heeft. Van de recent afgestudeerden van het HBO blijkt slechts 
een zeer gering percentage in deeltijd werkzaam te zijn. Op MBO-niveau blijkt er vaker sprake te zijn van part-time banen. Het blijkt dat een deel van de schoolverlaters van het technisch MBO naast het werk een aanvullende cursus volgt. Vooral de schoolverlaters van de opleidingen wegen waterbouwkunde en motorvoertuigentechniek hebben nogal eens geen volledige baan. Bij het opleidingstype MBO technisch laboratorium is het aandeel deeltijdwerkers daarentegen beperkt.

Van de VBO-schoolverlaters bekleedt een groot deel een part-time functie. Dit hangt in belangrijke mate samen met de doorstroom naar het leerlingwezen, waarbij er automatisch sprake is van werken en leren. Opvallende uitzondering is daarbij de opleiding VBO grafische techniek, waar in vergelijking met de andere opleidingen van het voorbereidend technisch onderwijs veel minder schoolverlaters in deeltijd werkzaam zijn.

\section{Conjunctuurgevoeligheid}

Naast de hierboven gepresenteerde indicatoren die een beeld schetsen van de actuele marktpositie van schoolverlaters en recent afgestudeerden, bieden de RUBS- en de $H B O$ Monitor-gegevens tevens de mogelijkheid om inzicht te verschaffen in de risicopositie van de onderscheiden opleidingen. Eén van die risico-indicatoren is de conjunctuurgevoeligheid, die aangeeft hoe stabiel de werkgelegenheid is in het segment, waarvoor men is opgeleid. De conjunctuurgevoeligheid wordt bepaald door de spreiding van de werkgelegenheid van de schoolverlaters en recent afgestudeerden over de verschillende bedrijfssectoren te relateren aan de sectorale werkgelegenheidsschommelingen in het verleden (zie verder De Grip. Van der Velden en Wieling, 1993b). Tabel 4.6 geeft een overzicht van de conjunctuurgevoeligheid, verbijzonderd naar opleidingsniveau en -richting.

Tabel 4.6. Conjunctuurgevoeligheid van de werkgelegenheid voor schoolverlaters en recent afgestudeerden naar opleidingsniveau en -richting

Hoger beroepsonderwijs

Technisch laboratorium

Technisch

bouwkunde

elektrotechniek

Middelbaar beroepsonderwijs

Technisch laboratorium

Technisch

bouwkunde

weg-en waterbouwkunde

metaalkunde 
Tabel 4.6. Conjunctuurgevoeligheid van de werkgelegenheid voor schoolverlaters en recent afgestudeerden naar opleidingsniveau en -richting (vervolg)

Opleidingsniveau en -richting

conjunctuurindicator

$\begin{array}{lr}\text { Voorbereidend beroepsonderwijs } & \\ \text { Technisch } & 2,19 \\ \quad \text { bouwtechniek } & 3,04 \\ \text { installatietechniek } & 3,11 \\ \text { metaalkunde } & 2,24 \\ \text { werktuigbouwkunde } & 1,52 \\ \text { motorvoertuigentechniek } & 2,70 \\ \text { elektrotechniek } & 1,75 \\ \text { grafische techniek } & 1,39 \\ \text { consumptieve techniek } & \\ \text { - geen informatie i.v.m. te weinig waarnemingen } & \end{array}$

Bron: RUBS/HBO-Monitor/ROA

In het algemeen kan worden geconcludeerd dat de conjunctuurgevoeligheid van de werkgelegenheid voor technisch opgeleiden vrij groot is (vergelijk ROA, 1993a en $1993 \mathrm{~b}$ ). Daarbij valt op dat de afgestudeerden van de laboratoriumopleidingen op zowel $\mathrm{HBO}$ - als $\mathrm{MBO}$ niveau iets minder in conjunctuurgevoelige sectoren terechtkomen. Op MBO-niveau blijkt verder dat voor de schoolverlaters in de richtingen fijnmechanische techniek en motorvoertuigentechniek de gevoeligheid voor conjuncturele schommelingen gering is in verhouding tot de andere technische opleidingen. De opleiding MBO bouwkunde wordt daarentegen gekarakteriseerd door een relatief grote conjunctuurgevoeligheid. Bij de VBO-richtingen motorvoertuigentechniek, grafische techniek en consumptieve techniek is de werkgelegenheidsontwikkeling relatief onafhankelijk van de conjunctuur, terwijl er voor de richtingen bouwtechniek en installatietechniek sprake van een erg hoge conjunctuurgevoeligheid.

\section{Uitwijkmogelijkheden}

Niet alleen de conjunctuurgevoeligheid, maar ook de vitwijkmogelijkheden naar andere beroepsgroepen geven een beeld van de risicopositie van technisch opgeleiden op de arbeidsmarkt. De uitwijkmogelijkheden worden bepaald met behulp van de Gini-Hirschman spreidingsindex. Deze index is gelijk aan 0 als de schoolverlaters en recent afgestudeerden slechts in één beroep terechtkomen en gelijk aan 1 als de werkgelegenheid precies gelijk over alle beroepen is verdeeld (zie ook De Grip, Van der Velden en Wieling, 1993b). Tabel 4.7 geeft voor de onderscheiden technische opleidingen een beeld van de uitwijkmogelijkheden naar andere beroepsgroepen. Daarbij zijn de beroepen op een lager niveau dan de genoten opleiding buiten beschouwing gelaten.

De tabel laat duidelijk zien dat het van belang is om de vitwijkmogelijkheden te bekijken op het niveau van opleidingen en niet van opleidingstypen. De resultaten op dit laatste (hoge) aggregatieniveau suggereren dat de uitwijkmogelijkheden voor technisch opgeleiden relatief 
hoog $z_{i j n}{ }^{19}$. Indien echter een verbijzondering wordt gemaakt naar opleiding, dan blijkt de arbeidsmarktflexibiliteit aanmerkelijk geringer te zijn (zie ook Wieling, De Grip en Van der Velden, 1992).

Tabel 4.7. Uitwijkmogelijkheden naar beroepen op een aansluitend of hoger functieniveau voor schoolverlaters en recent afgestudeerden naar opleidingsniveau en -richting 1992

Opleidingsniveau en -richting

spreidingsindex

Hoger beroepsonderwijs

Technisch laboratorium

Technisch

0,91

bouwkunde

0,74

werktuigbouwkunde

0,79

elektrotechniek

0,72

Middelbaar beroepsonderwijs

$\begin{array}{lr}\text { Technisch laboratorium } & 0,41\end{array}$

$\begin{array}{lr}\text { Technisch } & 0,95\end{array}$

$\begin{array}{lr}\text { bouwkunde } & 0,82\end{array}$

$\begin{array}{lc}\text { weg- en waterbouwkunde } & \dot{0}, 88 \\ \text { metaalkunde } & 0,88\end{array}$

$\begin{array}{lr}\text { fijnmechanische techniek } & 0,79\end{array}$

$\begin{array}{lr}\text { werktuigbouwkunde } & 0,89\end{array}$

$\begin{array}{lr}\text { motorvoertuigentechniek } & 0,74\end{array}$

$\begin{array}{lr}\text { elektrotechniek } & 0,84\end{array}$

procestechniek

Voorbereidend beroepsonderwijs

$\begin{array}{lr}\text { Technisch } & 0,94 \\ \text { bouwtechniek } & 0,63 \\ \text { installatietechniek } & 0,58 \\ \text { metaalkunde } & 0,94 \\ \text { werktuigbouwkunde } & 0,62 \\ \text { motorvoertuigentechniek } & 0,72 \\ \text { elektrotechniek } & 0,72 \\ \text { grafische techniek } & 0,67 \\ \text { consumptieve techniek } & \\ =\text { geen informatie i.v.m. te weinig waarnemingen } & \end{array}$

Bron: RUBS/HBO-Monitor/ROA

Op HBO-niveau blijken de afgestudeerden in de richting technisch laboratorium het meest beperkte arbeidsmarktbereik te hebben. Een soortgelijk beeld wordt op MBO-niveau geconstateerd. Bovendien valt op dat MBO-schoolverlaters doorgaans meer vitwijkmogelijkheden hebben dan de recent afgestudeerden van het HBO. Daarnaast blijkt dat bij de schoolverlaters van het VBO de uitwijkmogelijkheden in vergelijking met het algemene beeld

19. Een dergelijk resultaat wordt ook in het informatiesysteem onderwijs-arbeidsmarkt verkregen (zie ROA, 1993a en 1993b). 
voor technisch opgeleiden het kleinst zijn. Daarbij is de arbeidsmarktflexibiliteit met name gering voor de schoolverlaters met als specialisatie bouwtechniek, installatietechniek of motorvoertuigentechniek. Opvallend is dat de schoolverlaters van de opleiding VBO metaalkunde wel een groot arbeidsmarktbereik hebben.

Tabel 4.8. Percentage schoolverlaters en recent afgestudeerden dat niet in een technisch beroep werkzaam is naar opleidingsniveau en -richting 1992

Opleidingsniveau en -richting

$\%$

Hoger beroepsonderwijs

Technisch laboratorium 37

Technisch 25

bouwkunde 5

werktuigbouwkunde $\quad 12$

elektrotechniek $\quad 39$

Middelbaar beroepsonderwijs

$\begin{array}{lr}\text { Technisch laboratorium } & 27\end{array}$

Technisch $\quad 35$

bouwkunde 14

weg- en waterbouwkunde

$\begin{array}{ll}\text { metaalkunde } & 12 \\ \text { fijmmechanische techniek } & 36\end{array}$

werktuigbouwkunde $\quad 22$

motorvoerturgentechniek $\quad 21$

elektrotechniek 99

procestechniek

Voorbereidend beroepsonderwijs

Technisch

bouwtechniek

installatietechniek 8

metaalkunde $\quad 24$

werktuigbouwkunde

motorvoertuigentechniek $\quad 22$

elektrotechniek 27

$\begin{array}{ll}\text { grafische techniek } & 25\end{array}$

consumptieve techniek 69

. = geen informatie 1.v.m. te weinig waarnemingen

Bron: RUBS/HBO Monitor/ROA

Het arbeidsmarktbereik van schoolverlaters en recent afgestudeerden kan ook op een andere manier worden belicht. In tabel 4.8 wordt een overzicht gegeven van het percentage werkenden dat niet in een technisch beroep ${ }^{20}$ terechtkomt. Dit geeft een indicatie van de "uitval' van technisch opgeleiden die optreedt bij de arbeidsmarktintrede. Deze uitval kan als een verdere

20. Volgens de ROA-beroepenclassificatie zijn dit de beroepen, waarvan de code begint met een 3 . Een overzicht van deze beroepen is gegeven in bijlage $A$. 
vernauwing van de trechter naar de technische richting, zoals die onlangs door Willems en De Grip (1993) is gepresenteerd, worden gezien.

Op HBO-niveau blijken vooral veel afgestudeerden van de opleidingen technisch laboratorium en elektrotechniek niet in een technisch beroep werkzaam te zijn. Hierboven is reeds geconstateerd dat de werkloosheid voor afgestudeerden in de elektrotechniek momenteel hoog is. Deze overschotten op de arbeidsmarkt hebben er waarschijnlijk toe geleid dat een deel van de werkzoekenden in een andere arbeidsmarktsegment is terechtgekomen. Nadere analyses wijzen uit dat het overgrote merendeel van deze afgestudeerden werkzaam is in de beroepsklasse 'Systeemanalisten, -programmeurs en -beheerders', die formeel niet tot de technische, maar tot de economisch-administratieve beroepen, wordt gerekend. De HBO-ers bouwkunde en werktuigbouwkunde blijken hoofdzakelijk wel in de technische richting werkzaam te zijn.

Bij de technisch opgeleiden op MBO-niveau valt vooral op dat bij de schoolverlaters met als opleiding bouwkunde en metaalkunde het deel dat in een technisch beroep terechtkomt het grootst is. Ook bij de VBO-ers bouwtechniek en installatietechniek is dit het geval. Dit is in overeenstemming met het hierboven geconstateerde beeld dat de uitwijkmogelijkheden voor de schoolverlaters in deze twee richtingen gering zijn. Niet verrassend is tenslotte dat bij de richting consumptieve techniek het percentage schoolverlaters dat niet in de technische richting werkzaam is, relatief groot is.

\section{Resumé}

De marktpositie van schoolverlaters en recent afgestudeerden van de technische opleidingen kan niet eenduidig worden getypeerd. Voor de ene studierichting is de werkloosheid hoog, maar verdienen de werkenden wel een relatief hoog inkomen, terwijl bijvoorbeeld voor een andere studierichting de werkloosheid weliswaar lager is, maar een groot aantal werkenden in hun kwalificaties wordt onderbenut. Aan het slot van deze paragraaf zullen de belangrijkste kenmerken van de marktpositie van de technische opleidingen nog eens op een rijtje gezet.

Bij het $H B O$ valt op dat vooral de recent afgestudeerden in de elektrotechniek momenteel met een verhoudingsgewijs hoge werkloosheid te kampen hebben. Daar staat echter tegenover dat degenen die wel werk hebben gevonden, een relatief hoog inkomen verdienen. De afgestudeerden van de opleiding HBO technisch laboratorium verdienen daarentegen gemiddeld genomen een lager inkomen, maar voor hen geldt dat de mate van onderbenutting relatief gering is. Deze opleiding heeft als min of meer structureel voordeel dat de werkgelegenheid vrij ongevoelig is voor conjuncturele schommelingen. Van de andere kant zijn de uitwijkmogelijkheden voor deze opleiding gering, hetgeen het risico van een dergelijke opleidingskeuze vergroot. Tot slot blijkt dat relatief veel recent afgestudeerden in de richting technisch laboratorium niet in een technisch beroep werkzaam zijn. Hetzelfde geldt voor de afgestudeerden in de richting elektrotechniek. Deze laatste groep blijkt in grote mate te zijn uitgeweken naar de automatiseringsbranche. 
Op MBO-niveau blijkt de werkloosheid vooral hoog te zijn onder de schoolverlaters met als specialisatie technisch laboratorium of fijnmechanische techniek. Voor de eerstgenoemde opleiding geldt echter aan de andere kant dat het gemiddelde inkomen van de werkenden relatief hoog is, terwijl bij de tweede opleiding de mate van onderbenutting in vergelijking met de andere technische MBO-opleidingen gering is. De richtingen bouwkunde en motorvoertuigentechniek worden gekenmerkt door een relatief lage werkloosheid. Ook onder de schoolverlaters van MBO metaalkunde is de werkloosheid laag, maar het blijkt dat voor de nieuwkomers met deze opleidingsachtergrond de arbeidsmarktintrede toch moeizamer verloopt, hetgeen niet alleen tot uiting komt door een relatief lange werkloosheidsperiode direct na het schoolverlaten, maar ook in het feit dat een erg groot deel van de schoolverlaters een baan onder hun niveau heeft moeten accepteren. Hierdoor is ook het gemiddelde loon van de werkenden verhoudingsgewijs laag. Ook voor de schoolverlaters in de richting elektrotechniek is de mate van onderbenutting relatief hoog, maar voor deze richting komt dit niet of nauwelijks tot uiting in een lagere beloning.

De opleiding MBO bouw heeft als belangrijkste nadeel dat de conjunctuurgevoeligheid van de werkgelegenheid groter is dan bij de andere technische MBO-opleidingen. Het blijkt dat vrijwel alle schoolverlaters in een technisch beroep terechtkomen. Ook degenen die als specialisatie metaalkunde hebben gekozen, komen in grote mate in het technische segment van de arbeidsmarkt terecht. De werkgelegenheid in de bedrijfssectoren waarin de schoolverlaters van de opleidingen metaalkunde, motorvoertuigentechniek en technisch laboratorium emplooi vinden, zijn relatief ongevoelig voor conjuncturele schommelingen. Voor de laatstgenoemde opleiding staat daar echter als negatief risico-aspect tegenover dat de schoolverlaters weinig uitwijkmogelijkheden naar andere beroepsgroepen hebben.

Voor het VBO kan worden geconcludeerd dat de werkloosheid met name hoog is voor de richtingen elektrotechniek en grafische techniek. Bij deze laatste opleiding wordt bovendien een groot deel van de werkenden in hun kwalificaties onderbenut. Daar staat tegenover dat het gemiddelde inkomen voor deze schoolverlaters relatief hoog is. Degenen die de richting motorvoertuigentechniek hebben gekozen verdienen daarentegen gemiddeld een relatief laag inkomen. Daarnaast is een min of meer structurele risicofactor bij deze opleiding dat de uitwijkmogelijkheden naar andere beroepen gering zijn. Dit geldt overigens ook voor de richtingen bouwtechniek en installatietechniek. De schoolverlaters van deze opleidingen zijn meer nog dan andere technisch opgeleiden op VBO-niveau grotendeels werkzaam in een beperkt aantal technische beroepen. Dit maakt bovendien dat men hoofdzakelijk is aangewezen op de conjunctuurgevoelige bouwsector. 


\section{BESLUIT}

\section{Samenvatting en conclusies}

In dit rapport is uitgebreid ingegaan op de vraag of het mogelijk is om de arbeidsmarktprognoses die door het ROA in het kader van het informatiesysteem onderwijs-arbeidsmarkt onlangs zijn opgesteld voor het technisch onderwijs verder te verbijzonderen dan momenteel het geval is. Met het oog hierop is in hoofdstuk 2 eerst ingegaan op de Nederlandse data-infrastructuur met betrekking de arbeidsmarkt voor technisch opgeleiden. Tevens zijn enkele kerngegevens, zoals het aantal werkenden, de man/vrouw-verhouding, de belangrijkste bedrijfssectoren en de belangrijkste beroepsklassen, per opleiding weergegeven. Met betrekking tot de werkloosheid zijn momenteel nauwelijks gegevens beschikbaar. Om toch enig zicht te krijgen op de werkloosheidsproblematiek zijn daarom in hoofdstuk 2 de sterk verouderde en 'vervuilde' werkloosheidsgegevens van de Arbeidsvoorzieningsorganisatie gepresenteerd.

Vervolgens is in hoofdstuk 3 kort ingegaan op de prognosemodellen die het ROA hanteert bij het opstellen van de middellange-termijn arbeidsmarktprognoses, verbijzonderd naar beroep en opleiding. Belangrijk daarbij is dat wordt uitgegaan van een 'stroomcijfer'-aanpak, waarbij prognoses van de verwachte ontwikkelingen over een bepaalde periode worden opgesteld. Binnen het kader van een dergelijke stromenaanpak is de haalbaarheid van het opstellen van gedetailleerde prognoses voor technici nagegaan.

Geconcludeerd kan worden dat een verdere verbijzondering van de arbeidsmarktprognoses voor technisch opgeleiden in de meeste gevallen mogelijk is. Vooralsnog kan daarbij geen gebruik worden gemaakt van op dit lagere aggregatieniveau gespecificeerde modellen voor de uitbreidings- en de vervangingsvraag. Daarvoor is het noodzakelijk te beschikken over een langere tijdreeks van de gegevens op het vereiste aggregatieniveau. Momenteel is een dergelijke tijdreeks niet beschikbaar. Een goed alternatief voor een dergelijke aanpak is echter om de bestaande modellen en modelresultaten op het hogere aggregatieniveau te combineren met actuele gegevens op een meer gedetailleerd niveau. Zo wordt gebruik gemaakt van de ontwikkelingen die met behulp van de huidige modellen worden geprognosticeerd, naast eventuele structurele verschillen tussen de opleidingen birnen een bepaald opleidingstype. Bij dit laatste kan men bijvoorbeeld denken aan een andere verdeling van de onderscheiden opleidingen over de beroepen.

Het is op deze plaats van belang om op te merken dat er in wezen altijd een trade-off bestaat tussen de mate van detaillering en de betrouwbaarheid van de prognoseresultaten. Specifiek in de context van dit rapport betekent dit dat er bijvoorbeeld bij het prognosticeren van het aantal nieuwkomers op de arbeidsmarkt, en dan vooral bij de MBO- en de VBO-opleidingen, enkele belangrijke aanvullende veronderstellingen zullen moeten worden gemaakt. Dit zou kunnen worden aangegrepen om enkele verschillende scenario's door te rekenen, waardoor tevens een beeld kan worden verkregen van de gevoeligheid van de prognoseresultaten. 
De verdere detaillering van de in het huidige informatiesysteem onderwijs-arbeidsmarkt onderscheiden opleidingstypen, is een zeer zinvolle uitbreiding van dit informatiesysteem. Op grond van het haalbaarheidsonderzoek, waarover in dit rapport verslag is gedaan, blijkt dat een dergelijke uitbreiding voor een groot aantal richtingen mogelijk is. Voor een beperkt aantal (kleinere) richtingen is vooralsnog onduidelijk of het mogelijk is prognoses op te stellen.

Globaal gesproken kan echter worden opgemerkt dat het daadwerkelijk uitvoeren van een dergelijke prognosestudie een beter zicht zal geven op de eventuele specifieke problemen die hierbij kunnen optreden. Met name voor de kleine opleidingen waarvoor in dit rapport is aangegeven dat het opstellen van prognoses waarschijnlijk niet haalbaar zal zijn, zou kunnen blijken dat er toch enige indicaties kunnen worden gegeven van de te verwachten toekomstige ontwikkelingen op de arbeidsmarkt. Bij de uitvoering van zo'n prognosestudie kan tevens de in dit rapport gepresenteerde opleidingsindeling, indien nodig, worden aangescherpt.

Gezien de voortdurende belangstelling waarin de arbeidsmarkt voor technici staat en de onduidelijkheid die hierover bestaat, is het van belang een goed instrument te hebben om de arbeidsmarkt voor technici adequaat te kunnen monitoren. Van een dergelijk instrument zou regelmatig, bijvoorbeeld tweejaarlijks, verslag moeten worden gedaan in een, wat zou kunnen worden genoemd Trendrapport arbeidsmarkt technisch opgeleiden. Daarbij gaat het zowel om de huidige arbeidsmarktsituatie als om de verwachte situatie op middellange termijn. Het verfijnen van de arbeidsmarktprognoses van het ROA zou een eerste aanzet voor een dergelijk instrument kunnen zijn.

Als uitbreiding op de huidige ROA-prognosemodellen zou overigens kunnen worden overwogen om de prognoses voor technisch opgeleiden voor de iets langere termijn op te stellen, bijvoorbeeld tot het jaar 2000 in plaats van tot 1998. Ook zouden, zoals gezegd, in plaats van én prognose verschillende 'beleidsrijke' scenario's kunnen worden doorgerekend ${ }^{21}$. Deze zouden betrekking kunnen hebben op alle drie de elementen van het prognosemodel. Voor de uitbreidingsvraag zouden beide CPB-scenario's kunnen worden uitgewerkt (zie CPB, 1993). Ook is het mogelijk om door te rekenen wat een extra groei van een bepaalde bedrijfssector voor gevolgen heeft voor de werkgelegenheid voor technisch opgeleiden. Ten aanzien van de vervangingsvraag kunnen bijvoorbeeld scenario's worden gerelateerd aan mogelijke wijzigingen in de VUT-regeling of veranderingen in de arbeidsmarktuitstroom naar de WAO. Met behulp van scenario's met betrekking tot de instroom van schoolverlaters kan worden nagegaan wat de effecten zullen zijn van veranderingen in het keuzegedrag van leerlingen, bijvoorbeeld mede als gevolg van specifieke overheidscampagnes op dit punt.

Naast het opstellen van prognoses of scenario's is het, zoals gezegd, aan te bevelen om ook de

21. Dit kan worden vergeleken met de aanpak die De Grip, Berendsen, Borghans en Dekker (1993) hebben gehanteerd bij de Toekomstverkenning leerlingwezen. 
$-45-$

actuele marktpositie en de risicopositie van technisch opgeleiden goed in kaart te brengen. In dit rapport is daartoe reeds een aanzet gegeven. Het is echter wenselijk om, zoals in hoofdstuk 4 reeds is aangegeven, enkele aanvullende arbeidsmarktgegevens op basis van de $E B B$ te verzamelen. Daarnaast bieden de gegevens van RUBS en de HBO-Monitor nog meer analysemogelijkheden dan in hoofdstuk 4 zijn gepresenteerd. Zo zou bijvoorbeeld met behulp van deze enquête-onderzoeken een beeld kunnen worden verkregen van de kwaliteit van de opleiding. Daarbij kan worden gedacht aan de mening van de schoolverlaters en recent afgestudeerden of de aandacht die in het curriculum is besteed aan een aantal aspecten (algemene vaktheoretische kennis, specialistische vakkennis, toepassen van kennis in de praktijk, organiseren e.d.) voldoende is geweest. In dit verband kan bovendien worden opgemerkt dat voor het wetenschappelijk onderwijs helaas geen systematisch onderzoek onder de afgestudeerden plaatsvindt, dat enigszins vergelijkbaar is met de HBO-Monitor en de RUBS-enquête. Gezien de recente discussie over de kwaliteit van de technische studies, de vereiste lengte van de studieduur en het door het Ministerie van Onderwijs en Wetenschappen aangezwengelde debat over de doorstroom binnen het hoger onderwijs ('stapelen'), wordt de behoefte aan een dergelijk monitoring-instrument ongetwijfeld steeds groter. 


\section{LITERATUUR}

Berendsen, H., R.J.P. Dekker, A. de Grip, P.J.E. van de Loo (1992), Prognose arbeidsmarktinstroom van schoolverlaters per opleidingstype, ROA-W-1992/2, Maastricht.

Berendsen, H. A. de Grip, M.H. Wieling, E.J.T.A. Willems (1992a), Regionale arbeidsmarktinformatie naar opleiding en beroep, ROA-R-1992/2, Maastricht.

Berendsen, H. A. de Grip, M.H. Wieling, E.J.T.A. Willems (1992b), Arbeidsmarktinformatie naar opleiding en beroep voor de provincie Noord-Holland, ROA-R-1992/3, Maastricht.

Berendsen, H. A. de Grip, M.H. Wieling, E.J.T.A. Willems (1993), Regionale arbeidsmarktprognoses naar opleiding en beroep, Maandschrift Economie, jrg. 57, nr. 2, blz. 155-169.

Borghans, L., H. Heijke (1993a), Het voorspellen van de beroepenstructuur van bedrijfstakken binnen het kader van het Athena-model, ROA, Maastricht, te verschijnen

Borghans, L., H. Heijke (1993b), Forecasting the Educational Structure of Occupations: $A$ Manpower Requirements Approach with Substitution, ROA-RM-1993/2E, Maastricht.

Centraal Bureau voor de Statistiek (1993), Enquête Beroepsbevolking 1992, Voorburg/Heerlen.

Centraal Planbureau (1993), Centraal Economisch Plan 1993, SDU-Uitgeverij, Den Haag.

Dekker, R.J.P., A. de Grip, H. Berendsen, M.H. Wieling, E.J.T.A. Willems (1992), Methodiek en structuur arbeidsmarktmodule /-See! 1991, ROA-W-1992/1, Maastricht.

Detmar, H., B. Dekker (1987), Het werkloosheidscijfer opnieuw beschouwd, Research voor Beleid, Leiden.

Grip, A. de (1987), Onderwijs en arbeidsmarkt: scholingsdiscrepanties, proefschrift, VUUitgeverij, Amsterdam.

Grip, A. de, H. Berendsen, L. Borghans, R.J.P. Dekker (1993), Toekomstverkenning leerlingwezen, ROA-R-1993/4, Maastricht.

Grip, A. de, R. Dekker (1993), Winnaars en verliezers op de arbeidsmarkt 1985-1990, Tijdschrift voor Arbeidsvraagstukken, jrg. 9, nr. 3, blz. 220-229.

Grip, A. de, R.K.W. van der Velden, M.H. Wieling (1993a), De inpassing van schoolverlatersinformatie in het ROA-informatiesysteem onderwijs-arbeidsmarkt, ROA-R-1993/9, Maastricht. 
Grip, A. de, R.K.W. van der Velden, M.H. Wieling (1993b), De arbeidsmarktpositie van MDGOschoolverlaters, Tijdschrift voor Arbeidsvraagstukken, jrg. 9, nr. 3, blz. 241-252.

Loo, P.J.E. van de, R.J.P. Dekker, A. de Grip (1992), Arbeidsmarktsegmentatie als uitgangspunt voor een beroepenclassificatie, Tijdschrift voor Arbeidsvraagstukken, jrg. 8, nr. 1, blz. 19-31.

Loo, P.J.E. van de, R.K.W. van der Velden, M.H. Wieling (1993), De arbeidsmarktpositie van afgestudeerden van het hoger beroepsonderwijs; HBO-Monitor 1992, Voorlichtingsdienst HBORaad, 's-Gravenhage.

Ministerie van Onderwijs en Wetenschappen (1993a), Referentieraming 1993, Zoetermeer.

Ministerie van Onderwijs en Wetenschappen (1993b), WO-Verdeelraming 1992, Zoetermeer.

Researchcentrum voor Onderwijs en Arbeidsmarkt (1993a), De arbeidsmarkt naar opleiding en beroep tot 1998, ROA-R-1993/10, Maastricht.

Researchcentrum voor Onderwijs en Arbeidsmarkt (1993b), Statistische bijlage: De arbeidsmarkt naar opleiding en beroep tot 1998, ROA-R-1993/10B, Maastricht.

Wieling, M.H., R.J.P. Dekker, A. de Grip (1991), Landelijke en regionale werkloosheidsindicatoren 1991, ROA-R-1991/8, Maastricht.

Wieling, M.H., A. de Grip, R.K.W. van der Velden (1992), Indicatoren onderwijs-arbeidsmarkt technisch en economisch onderwijs (LBO en MBO), ROA-R-1992/4, Maastricht.

Wieling, M.H., P.J.E. van de Loo, R.K.W. van der Velden (1993a), Waar komen onze schoolverlaters terecht? De uitstroom en bestemming van het schooljaar 1990/1991, LDC, Leeuwarden.

Wieling, M.H., P.J.E. van de Loo, R.K.W. van der Velden (1993b), Waar komen de schoolverlaters van het middelbaar technisch onderwijs terecht? De uitstroom en bestemming van het schooljaar 1990/1991, LDC Leeuwarden.

Willems, E.J.T.A., A. de Grip (1992), De vervangingsvraag naar beroep en opleiding, Maandschrift Economie, jrg. 56, nr. 6, blz. 493-505.

Willems, E.J.T.A., A. de Grip (1993), Jongeren en techniek; Studie- en beroepskeuzes, waardering en beeldvorming ten aanzien van techniek, Beleidsstudies Technologie Economie nr. 26, Ministerie van Economische Zaken, Den Haag. 


\section{BIJLAGE A. TECHNISCHE BEROEPSKLASSEN EN OPLEIDINGSTYPEN IN HET ROA-INFORMATIESYSTEEM ONDERWIJS-ARBEIDSMARKT}

Tabel A.1. Technische beroepsklassen in het ROA-informatiesysteem onderwijs-arbeidsmarkt

ROA- Beroepsklassenaam

code

3011 heftruck- en hefvorkchauffeurs

3012 machinisten bouw en industrie

3021 leidinggevenden produktie, bedrijfskundigen en directeuren

3022 technische en medische vertegenwoordigers

3023 technische tekenaars

3024 technische analisten en amanuenses

3031 beta-onderzoekers en technische vakspecialisten

3111 voedings- en genotmiddelenbereiders

3112 bakkers en (industrieel) bakkerijpersonee!

3211 produktiepersoneel textielindustrie

3212 stoffeerders, schoen- en lederwarenmakers

3213 kleding-e.a. textielproduktenmakers

3311 houtwaren-, papier- en kartonmakers

3312 timmerlieden e.a. houtbewerkers

3411 drukkers en produktiepersoneel grafische industrie

3511 produktiepersoneel chemische industrie

3611 delfstotten(be)werkers. metaalvervaardigers

3612 machinale metaalbewerkers

3613 lassers en constructiewerkers

3614 machinebank-, plaatwerkers en gereedschapsmakers

3615 onderhoudsmonteurs, fietsen- en instrumentmakers

3621 automonteurs en (motoririjwielherstellers

3622 middelbare (scheeps)werktug(bouw)kundigen

3631 hogere werktuigkundigen

3711 monteurs en controleurs van elektrotechnische produkten

3721 elektriciens, elektro- en telecomlonderhoudsimonteurs

3731 hogere elektrotechnici

3811 produktiepersoneel bouwmaterialen, glas- en aardewerkindustrie

3911 metselaars, tegelzetters, straatmakers en stukadoors

3912 betonwerkers, dakdekkers, isoleerders en glaszetters

3913 huls- en constructieschilders

3914 loodgieters, pijpfitters en verwarmingsmonteurs

3915 gespecialiseerde bouwvak-, wegenbouw- en reinigingswerkers

3921 bouwkundige technici, opzichters en werkvoorbereiders

3931 architecten, geodeten e.a. hogere bouwkundigen 
-49 .

Tabel A.2. Technische opleidingstypen in het ROA-informatiesysteem onderwijs-arbeidsmarkt

SOI- Opleidingstypenaam

code

VBO technisch

MBO technisch laboratorium

MBO technisch

$436-439$

531

$536-539$

631

HBO technisch laboratorium

HBO technisch

WO wis- en natuurkunde

636-639 WO technisch 


\section{BIJLAGE B. OPLEIDINGSINDELING TECHNISCH ONDERWIJS}

Opleidingsniveau en -richting

Wetenschappelijk onderwijs

wis-en natuurkunde

bouwkunde (incl. civiele techniek)

werktuigbouwkunde

elektrotechniek (incl. computerkunde/informatica)

overig

\section{Hoger beroepsonderwijs}

technisch laboratorium

bouwkunde (incl. weg-/waterbouwkunde)

werktuigbouwkunde

elektrotechniek (incl. computerkunde/informatica)

overig

Middelbaar beroepsonderwijs

technisch laboratorium

bouwkunde

weg- en waterbouwkunde

metaalkunde

fijnmechanische techniek

werktuigbouwkunde

motorvoertuigentechniek

elektrotechniek

procestechniek

overig

Voorbereidend beroepsonderwijs

bouwtechniek (incl. weg-/waterbouwkunde)

installatietechniek

metaalkunde

werktuigbouwkunde

motorvoertuigentechniek

elektrotechniek

grafische techniek

consumptieve techniek

overig
SOl-codes

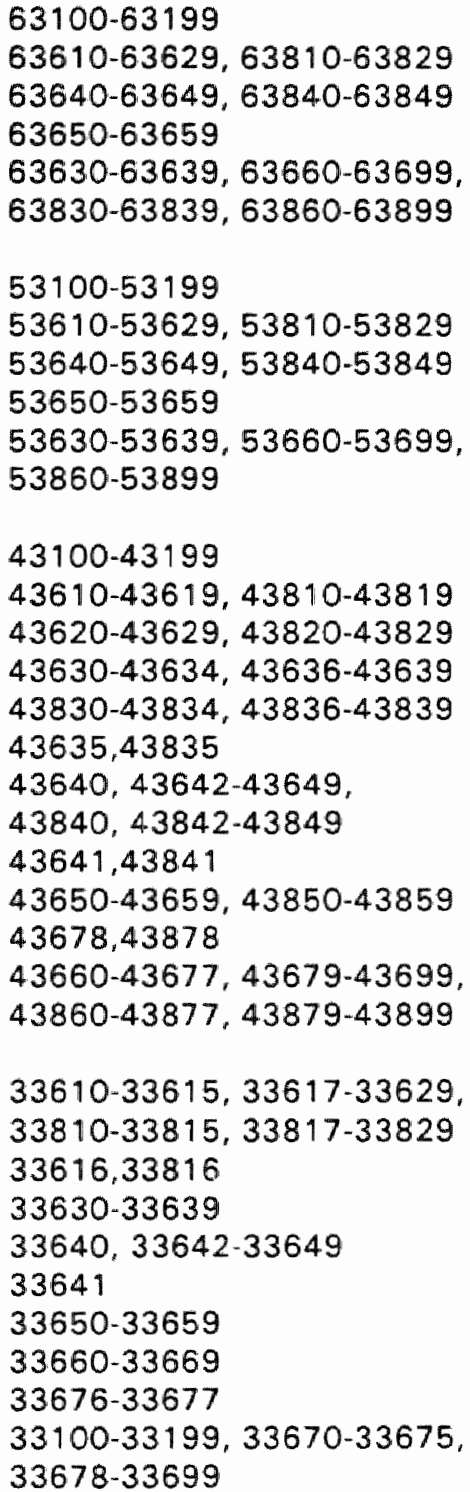




\section{BIJLAGE C. AANVULLENDE TABELLEN BIJ HOOFDSTUK 2}

Tabel C.1. Belangrijkste bedrijfssectoren ${ }^{1}$ van de werkende technisch opgeleiden naar opleidingsniveau en -richting 1992

Opleidingsniveau en -richting beroepsklasse

aantal werkenden

Wetenschappelijk onderwijs

Wis- en natuurkunde

onderwijs

14.000

Technisch

bouwkunde

overige commerciële dienstverlening

9.000

werktuigbouwkunde

elektrotechniek

overig

Hoger beroepsonderwijs

Technisch laboratorium

Technisch

bouwkunde

bouw

6.000

overige commerciële dienstverlening

13.000

openbaar bestuur, politie en defensie

werktuigbouwkunde

elektrotechniek

metaalindustrie

8.000

elektrotechnische industrie

7.000

handel

overige commercielle dienstverlening

10.000

6.000

overig

-

Middelbaar beroepsonderwijs

Technisch laboratorium

Technisch

bouwkunde

hout- en bouwmaterialenindustrie

7.000

metaalindustrie

6.000

bouw

77.000

handel

9.000

overige commerciêle dienstverlening

15.000

openbaar bestuur, politie en defensie

6.000

bouw

7.000

weg-en waterbouwkunde

metaalkunde

fijnmechanische techniek werktuigbouwkunde

motorvoertuigentechniek

openbaar bestuur, politie en defensie

6.000

metaalindustrie

28.000

transportmiddelenindustrie $\quad 6.000$

chemie

6.000

metaalindustrie

19.000

transportmiddelenindustrie $\quad 8.000$

energie

6.000

bouw

9.000

8.000

handel

6.000

vervoer en communicatie

overige commerciele dienstwerlening $\quad 13.000$

handel

7.000 
Tabel C.1. Belangrijkste bedrijfssectoren' van de werkende technisch opgeleiden naar opleidingsniveau en richting 1992 (vervolg)

procestechniek overig werktuigbouwkunde motorvoertügentechniek

elektrotechniek

grafische techniek consumptıeve techniek

(a) overige commerciële dienstverlening chemie

metaalindustrie

elektrotechnische industrie

energie

bouw

handel

vervoer en communicatie

overige commerciẻle dienstverlening chemie

voedings- en genotmiddelenindustrie papier en grafische industrie

metaalindustrie

handel

vervoer en communicatie

overige commerciële dienstverlening
27.000

6.000

15.000

17.000

11.000

26.000

23.000

13.000

10.000

8.000

15.000

26.000

7.000

28.000

6.000

12.000

\section{Voorbereidend beroepsonderwijs}

Technisch

bouwtechniek

installatietechniek

metaalkunde

\author{
hout- en bouwmaterialenindustrie \\ metaalindustrie \\ bouw \\ handel \\ vervoer en communicatie \\ overige commerciële dienstverlening \\ metaalind ustrie \\ transportmiddelenindustrie \\ bouw \\ handel \\ vervoer en communicatie \\ overige commerciële dienstverlening \\ openbaar bestuur, politie en defensie \\ handel \\ vervoer en communicatie \\ overige commerciële dienstverlening \\ metaalindustrie \\ elektrotechnische industrie \\ bouw \\ handel \\ vervoer en communicatie \\ voedings- en genotmiddelenindustrie \\ handel
}

11.000

7.000

61.000

10.000

11.000

7.000

38.000

9.000

16.000

15.000

16.000

8.000

6.000

7.000

7.000

9.000

7.000

6.000

15.000

7.000

6.000

8.000

6.000

\footnotetext{
'tenminste 5.000 werkenden
} 
Tabel C.2. Belangrijkste beroepsklassen' van de werkende technisch opgeleiden naar opleidingsniveau en -richting 1992

Opleidingsniveau en -richting

Wetenschappelijk onderwijs

Wis- en natuurkunde

Technisch

bouwkunde

werktuigbouwkunde

elektrotechniek

\section{Hoger beroepsonderwijs}

\section{Technisch laboratorium}

Technisch

bouwkunde

werktuigbouwkunde

elektrotechniek

\section{Middelbaar beroepsonderwijs}

\section{Technisch laboratorium}

\section{Technisch}

bouwkunde

weg-en waterbouwkunde metaalkunde beroepsklasse

aantal werkenden docenten voortgezet en hoger onderwijs

71.000

beta-onderzoekers en technische

vakspecialisten

systeemanalisten, -programmeurs en

-beheerders

5.000

architecten, geodeten e.a. hogere

bouwkundigen

8.000

technische analisten en amanuenses

leidinggevenden produktie, bedrijfskundigen en directeuren

bouwkundige technici, opzichters en

werkvoorbereiders

5.000

architecten, geodeten e.a. hogere

bouwkundigen

leidinggevenden produktie, bedrijfskundigen

en directeuren

leidinggevenden produktie, bedrijfskundigen

en directeuren

5.000

systeemanalisten, -programmeurs en

-beheerders leidinggevenden produktie, bedrijfskundigen

en directeuren

timmerlieden e.a. houtbewerkers

21.000

metselaars, tegelzetters, straatmakers en

stukadoors

37.000

8.000

huis- en constructieschilders

11.000

loodgieters, pijpfitters en

verwarmingsmonteurs

11.000

bouwkundige technici, opzichters en

werkvoorbereiders

leidinggevenden produktie, bedrijfskundigen

en directeuren

lassers en constructiewerkers

11.000

machinebank-, plaatwerkers en

gereedschapsmakers 